\title{
ASCENSÃO E CRISE DO GOVERNO DILMA ROUSSEFF E O GOLPE DE 2016: PODER ESTRUTURAL, CONTRADIÇÃO E IDEOLOGIA*
}

\author{
Pedro Paulo Zahluth Bastos ${ }^{a}$ \\ aProfessor Associado (Livre-Docente) do Instituto de Economia e pesquisador do Centro de Estudos de \\ Conjuntura e Política Econômica (CECON) da Universidade Estadual de Campinas (UNICAMP).
}

Artigo recebido em 07/02/2017 e aprovado em 07/03/2017.

RESUMO: O artigo procura entender o governo Dilma Rousseff e o Golpe de 2016 levando em consideração o poder estrutural do capital financeiro e as contradições inerentes aos modelos de crescimento econômico e coalizão política observados desde o governo Lula. Argumenta-se que o projeto econômico do governo Rousseff procurava superar algumas destas contradições. O governo, contudo, não foi capaz de realizar nem as reformas institucionais nem as repactuações políticas necessárias para o sucesso de seu projeto, em contexto de desaceleração cíclica e aguçamento da concorrência internacional e dos conflitos sociais no Brasil. A política econômica é avaliada desde a austeridade de 2011 até a de 2015, passando pela chamada Nova Matriz Econômica e seu desmonte gradual em 2013. Analisa-se as origens da unificação da burguesia em torno a um programa neoliberal em 2016, assim como a relação entre a revolta das camadas médias e o ataque político-judicial resultante no Golpe de 2016.

PALAVRAS-CHAVE: Dilma Rousseff; Lulismo; golpe de 2016; Operação Lava-Jato; nova matriz econômica.

CLASSIFICAÇÃO JEL: O11; O54; P16.

\footnotetext{
* Agradeço os comentários a uma primeira versão deste texto em seminário realizado em 30/11/2016 com os professores Guilherme Melo, Pedro Rossi e Ricardo Carneiro (CECON); Andréia Galvão, Armando Boito e Sávio Cavalcante (CEMARX-UNICAMP); José Dari Krein e Marcelo Proni (CESIT-UNICAMP), além dos alunos Cauê Campos, Nátaly Santiago e Otavio Fonseca, poupando-os dos erros remanescentes. 


\title{
THE RISE AND FALL OF DILMA ROUSSEFF GOVERNMENT AND THE 2016 COUP: STRUCTURAL POWER, CONTRADICTION AND IDEOLOGY
}

\begin{abstract}
The article seeks to understand the Dilma Rousseff government and the 2016 coup, considering the structural power of the financial capital and the contradictions inherent to the models of economic growth and political coalition observed since the Lula administration. It is argued that the Rousseff government's economic project sought to overcome some of these contradictions. The government, however, was unable to carry out either the institutional reforms or the political changes necessary for the success of its project, in the context of an economic slowdown and the sharpening of international competition and social conflicts in Brazil. The economic policy is evaluated from the austerity of 2011 to that of 2015, passing through the so-called New Economic Matrix and its gradual dismantling in 2013. The origins of the bourgeoisie's unification around a neoliberal program in 2016 are analyzed, as well as the relationship between the middle-class revolt and the political-judicial attack resulting on the 2016 coup.
\end{abstract}

KEYWORDS: Dilma Rousseff; Lulism; 2016 Coup; Car-Wash Operation; new economic matrix. 


\section{INTRODUÇÃO}

“Não vamos pagar o pato!” foi o lema que a Federação das Indústrias do Estado de São Paulo (FIESP) lançou para rejeitar elevação de tributos e defender o corte (seletivo) do gasto público em 2015. A mesma FIESP se colocaria no campo dos que pediam o impeachment da presidenta Dilma Rousseff, tendo financiado manifestações e até contribuído com acampamentos de militantes em frente à sua sede na Avenida Paulista.

Paradoxalmente, a política econômica do primeiro governo Dilma Rousseff tinha atendido a várias das bandeiras defendidas pela FIESP ao longo dos anos, no que se chamaria de "nova matriz econômica": redução de taxas de juros e tarifas de energia elétrica; desonerações tributárias e crédito subsidiado; desvalorização cambial e protecionismo industrial seletivo; concessões de serviços públicos para a iniciativa privada. Algumas dessas iniciativas foram, inclusive, solicitadas em documento entregue ao governo e assinado em conjunto com outras organizações empresariais e centrais sindicais em 2011.

No segundo governo, contudo, a presidenta reeleita Dilma Rousseff resolveu realizar um ajuste fiscal e monetário abrupto que surpreendeu muitos dos que, em sua base eleitoral, acreditaram em suas críticas de campanha à disposição de cortar e cortar dos candidatos de oposição. Dessa vez, atendia ao clamor de grupos empresariais que se colocaram contra a chamada "nova matriz econômica" e, além de motivos econômicos que podem ser discutidos, a virada parecia ter razões políticas.

Como a história se repete como farsa, a indicação, para o Ministério da Fazenda, do economista-chefe do principal banco privado brasileiro (Joaquim Levy do Bradesco) parecia querer repetir a manobra de conciliação de opostos executada por Luís Inácio Lula da Silva em 2003, moderando a oposição empresarial e recriando, quiçá, um grande pacto que incluía até a Federação Brasileira dos Bancos (FEBRABAN), cujos interesses foram atacados publicamente pela presidenta em 2012.

Ao contrário disso, ocorreu uma tendência de unificação da burguesia ou, pelo menos, de inação conivente do grande empresariado em torno da bandeira de impeachment de Dilma Rousseff, concluído em agosto de 2016. Por que isso ocorreu?

$\mathrm{O}$ artigo pretende levantar algumas hipóteses e trazer algumas evidências para responder à questão. $\mathrm{O}$ argumento central é que a mudança do cenário econômico depois da crise financeira global dificultou a conciliação dos interesses de diferentes frações da burguesia e que as reviravoltas da política econômica do primeiro governo Dilma Rousseff contribuíram para reforçar tanto a desaceleração cíclica quanto o descontentamento empresarial.

O objetivo do governo Rousseff era imenso: eliminar o rentismo com a dívida pública como meio sistemático de acumulação de capital (uma forma essencial de ganhar 
dinheiro da burguesia brasileira desde o início da década de 1980) e, assim, forçar a ampliação do investimento produtivo e em infraestrutura. A ação, contudo, foi precedida por políticas austeras que reforçaram a desaceleração cíclica e, depois, não foi acompanhada de uma ampla campanha pública pela hegemonia da interpretação técnica e convencional da questão perante a opinião pública. Isso permitiu que o poder estrutural do capital financeiro se reafirmasse, apresentando-se como meramente técnico e não como profundamente político, inclusive usando o controle dos meios de comunicação para taxar o governo de “irresponsável tecnicamente" e "politicamente populista”.

Ao mesmo tempo, os conflitos sociais se ampliavam de um modo que o governo não conseguia controlar, o que dificultava a conciliação de interesses entre classes. No plano da relação capital-trabalho, ganhos salariais propiciados pela redução do desemprego e pelo ativismo sindical manifesto no crescimento do número de greves vitoriosas eram objeto de reclamação empresarial crescente. No plano da relação entre Estado e movimentos populares, a pressão por bens públicos e direitos sociais manifesta, por exemplo, nas jornadas de junho de 2013, empurrava uma agenda de reivindicações de gasto público que dificilmente poderia ser atendida sem aumento da dívida pública, pressão "populista” para redução da taxa de juros e/ou uma reforma tributária que eliminasse privilégios empresariais.

A reação dos interesses empresariais afetados pela guerra dos juros e pelo avanço das demandas salariais e sociais contou com o controle dos meios de comunicação e com o vácuo deixado pelo governo na disputa pela opinião pública, pelo menos até a campanha eleitoral de 2014. Não foram poucos os economistas representantes de associações empresariais ou de think-tanks financiados por empresas que apontavam para a suposta necessidade de um ajuste no mercado de trabalho e de uma contração fiscal para restaurar a capacidade de crescimento de lucros e investimentos, ampliar a competitividade das empresas e limitar o crescimento da dívida pública. Algumas declarações de lideranças empresariais ocorreram no mesmo sentido. Esta agenda de reação contra as reivindicações trabalhistas e sociais crescentes foi reverberada por partidos que, na campanha de 2014, já alegavam que um ajuste era incontornável, o PSDB e a Rede.

Quando o embate público aberto foi realizado pela presidenta Dilma Rousseff, ou seja, na campanha presidencial de 2014, o resultado foi suficiente para deslegitimar as candidaturas de Marina Silva e Aécio Neves, acusando-as de cortejarem o interesse dos banqueiros e quererem trazer de volta a recessão e o desemprego. A disputa pela hegemonia pública foi abandonada inteiramente, porém, iniciado o segundo mandato, à medida que a agenda macroeconômica criticada foi implementada pelo governo reeleito, ainda que de forma menos radical do que proposto pela oposição, em 2015. 
O problema é que o segundo governo Dilma Rousseff incorreu no custo político de executar a agenda empresarial e conservadora sem, com isso, porém, recriar o amplo apoio empresarial gozado no início do primeiro mandato. Ao contrário, o resultado da virada de política econômica foi aprofundar a perda de lucratividade e o descontentamento empresarial, e também detonar uma grande perda de popularidade inclusive na base de apoio tradicional dos governos do Partido dos Trabalhadores (PT).

Em um momento de ampliação de conflitos sociais e políticos, e em uma fase de desaceleração do ciclo econômico, o governo preferiu realizar políticas que, teoricamente, apaziguariam a insatisfação empresarial, ainda que prejudicassem seus próprios aliados na base. O resultado foi o oposto do esperado: além de aprofundar a recessão e o afastamento empresarial, a virada na política econômica alienou parte da população para quem era verossímil a acusação de "estelionato eleitoral" (ou mesmo "traição") feita pelos grandes meios de comunicação e pela oposição partidária.

Realizar uma contração fiscal em meio a uma recessão sempre traz custos políticos mesmo para um governo com ampla governabilidade junto ao poder legislativo e grande popularidade perante os cidadãos. $\mathrm{O}$ custo político incorrido pela presidenta Dilma Rousseff aumentou porque os mecanismos tradicionais de governabilidade (distribuição de verbas, obras e cargos públicos) já seriam prejudicados pela contração fiscal e pela tentativa inicial de enfraquecer o peso do PMDB na base parlamentar do governo, mas foram praticamente implodidos pela Operação Lava-Jato.

De fato, a operação Lava-Jato minou os arranjos políticos tradicionais que contribuíram para a governabilidade dos governos petistas, além de reforçar a perda de popularidade do governo. Ela também neutralizou, pelo medo ou pela prisão, a camada empresarial mais próxima do governo. Paradoxalmente, o fato de o governo Dilma Rousseff apoiar a Lava-Jato enfraqueceu sua governabilidade em outro sentido. Políticos e empresários envolvidos em transações suspeitas tinham interesse evidente em substituir o governo por outro capaz de barrar ou limitar as apurações e patrocinar algum tipo de anistia dos crimes cometidos.

Sem a governabilidade tradicional, e sem popularidade, havia pouco que pudesse salvar o governo do ataque previsível de seus inimigos. O governo não caiu sem luta, mas, primeiro, a tentativa de convocar como ministro o ex-presidente Lula para remontar a governabilidade fracassou sob ataque da Operação Lava-Jato. Antes dessa tentativa desesperada, a tentativa de recompor com o PMDB com a transferência da coordenação política para Michel Temer fracassara, em meados de 2015, por sua afirmação pública como alternativa de poder para "reunificar o país" e, depois, pela apresentação explícita de um programa alternativo, Uma Ponte para o Futuro. Segundo, o apelo às ruas em 2016 veio tarde demais para um governo que desperdiçara sua popularidade pouco depois de ser reeleito e que ainda não sinalizava com a ampliação de empregos, salários e direitos sociais, antes pelo contrário. 
$\mathrm{Na}$ primeira seção, a seguir, discute-se o poder estrutural do capital financeiro sobre a política econômica no Brasil. Na segunda, o modelo de crescimento verificado ao longo do governo Lula e algumas de suas restrições. Na terceira, a política econômica e seus resultados no primeiro governo Dilma Rousseff. Na quarta, a resistência do capital financeiro à Nova Matriz Econômica e a unificação da burguesia contra direitos trabalhistas e sociais. Na quinta, aborda-se a revolta de camadas médias e sua relação com o ataque político-judicial representado pela Operação Lava-Jato. Na sexta e última seção, avalia-se o segundo governo, enfatizando a política econômica e a dinâmica política que levou ao impeachment.

\section{O PODER ESTRUTURAL DO CAPITAL FINANCEIRO NO BRASIL}

Dois anos e suas circunstâncias: 2015 não era 2003. O não reconhecimento dessa diferença teve consequências enormes para os projetos das esquerdas no Brasil.

Não aconteceu por acaso: foi a falência da utopia neoliberal que criou a oportunidade para a vitória de projetos de esquerda na América do Sul desde 1998. No Brasil, o sonho vendido por Collor e Cardoso era que a abertura comercial, a privatização e a "flexibilização" de contratos de trabalho tornariam as empresas nacionais e filiais eficientes e fortemente exportadoras. Assim, gerariam as reservas cambiais necessárias para bancar mais um ciclo de endividamento externo e as remessas de juros, lucros e dividendos associados às privatizações, fusões e aquisições de patrimônio local pelo capital financeiro global.

Não deu certo, mas a crise cambial, financeira e fiscal paradoxalmente aumentou o poder estrutural do capital financeiro, quando o Real passou a flutuar com pouco controle nacional em 1999. FHC já recorrera ao FMI em novembro de 1998, obtendo US\$ 41,5 bilhões para rolar a dívida privada.Ofereceu como contrapartida metas de superavit fiscal primário pelos três anos seguintes, antecipando o primeiro pilar do novo tripé de política econômica que seria institucionalizado com a crise da âncora cambial em 1999: taxa de juros elevada o suficiente para compensar o risco de depreciação cambial, e meta de superavit primário alta o suficiente para compensar o custo fiscal dos juros elevados da dívida pública.

Os novos acordos em 2001 (US\$ 15,7 bilhões) e em 2002 (US\$ 37 bilhões) sinalizaram o fracasso da austeridade em recuperar as receitas do setor privado endividado em dólares e assegurar a rolagem voluntária dos passivos com novos influxos de financiamento externo. $\mathrm{O}$ terceiro acordo foi assinado em meio à campanha presidencial de 2002 e foi essencial para disciplinar as propostas de Luís Inácio Lula da Silva, que assinou uma "Carta ao Povo Brasileiro" comprometendo-se a respeitar os termos do acordo e, na prática, preservar o tripé macroeconômico. 
A postura inicial do governo Lula foi a de precaução tática, de modo a recuar e acumular forças para modificações posteriores da política econômica que melhor refletissem seu arco de apoio. Não obstante, o recuo tático implicou a consolidação de uma institucionalidade que condensava objetivos estratégicos do capital financeiro e lhe conferia significativo poder de veto diante de uma mudança desfavorável na luta ideológica e na correlação de forças.

Pode parecer paradoxal que o capital financeiro internacional ganhe ou pelo menos preserve poder exatamente quando crises cambiais e financeiras parecem anunciar o fracasso de um projeto nacional de inserção na globalização financeira. No entanto, dada a sucessão de crises que caracteriza a globalização, a saída de capitais é um valioso recurso de poder à disposição do capital financeiro para disciplinar a política econômica de países endividados, dependentes de financiamento externo e resistentes aos riscos de ostracismo que uma moratória da dívida externa pode implicar. A própria crise e reversão de um ciclo financeiro pode aumentar a influência dos intelectuais orgânicos que vocalizam os interesses do mercado financeiro, dado o grande potencial de crise sistêmica provocada pela fuga de capitais em massa de uma moeda e dos ativos nela denominados. A saída cria o vácuo para a voz quanto às condicionalidades institucionais e políticas afirmadas como necessárias para o retorno da "normalidade" financeira1.

É importante notar que Keynes havia proposto institucionalizar controles de capitais em Bretton Woods exatamente para conferir autonomia para Estados orientados por objetivos democráticos e insulá-los de pressões do mercado financeiro internacional. O bloqueio à mobilidade de capitais reforça o poder de Estado de definir a política macroeconômica sem concorrência com outros mercados para onde os capitais de curto prazo possam fugir, ou seja, sem pressão para a desregulamentação competitiva ou do aumento dos juros e outros incentivos para evitar a saída de capitais (BASTOS, 1996).

Ao revés, facilitar fuga de capitais e ataques especulativos para ameaçar ou gerar crises financeiras, e usá-las para forçar mudanças em direção de políticas market-friendly sempre foi um objetivo deliberado do movimento neoliberal. Friedrich von Hayek, Milton Friedman e James Buchanan alegaram que a fuga ou a vocalização da ameaça de fuga de capitais eram necessárias para disciplinar a política econômica e social segundo a opinião do mercado, principalmente em um Estado democrático (HARMES, 2012). Na década de 1990, o best-seller do jornalista Thomas Friedman (O

\footnotetext{
Para a saída e a voz como diferentes recursos de poder, eventualmente complementares, ver o estudo clássico de Albert Hirschman (1970). Para o poder estrutural do capital financeiro sobre a política econômica em condições institucionais de livre mobilidade internacional de capitais, ver Pauly (1995), Cox (1995) e Bastos (1996).
} 
Lexus e a Oliveira) popularizou essa visão ao alegar que a integração financeira global assegurava que os Estados que não seguissem o neoliberalismo seriam disciplinados e punidos pelo "rebanho eletrônico"

É claro que a capacidade de disciplinamento e punição é desigual a depender, primeiro, da posição do país na hierarquia de moedas: países emissores de moedas que denominam ativos internacionais e são demandadas como reservas de valor têm mais autonomia do que países endividados em moedas que não emitem. Segundo, depende da capacidade de países periféricos de acumular reservas cambiais para se precaver diante de contrações da liquidez internacional. Não surpreende que, depois das crises cambiais verificadas entre 1997 e 2002, os países periféricos tenham procurado acumular reservas cambiais para reduzir seu passivo externo líquido e ter um colchão para realizar política contracíclicas que, para desgosto dos portadores de títulos da dívida pública, podem recorrer à redução de juros e deficit fiscais primários ${ }^{3}$.

De todo modo, nas situações de crise, se o poder estrutural do capital financeiro for capaz de vencer resistências políticas, suas condicionalidades, normalmente expressas pelo Fundo Monetário Internacional (FMI), traduzem-se em reformas institucionais que, sob pretexto de reverter a saída de capitais, aumentam a voz do capital financeiro no próprio aparelho de Estado, nas instituições financeiras e nas regras de condução da política econômica ${ }^{4}$.

Nesse sentido, a crise de hegemonia e da estratégia de acumulação do capital financeiro pode levar a uma situação em que aumenta seu poder estrutural no interior do aparelho de Estado. Mesmo que isso não seja suficiente para gerar uma nova expansão puxada pelo influxo de investimentos externos, pode ser suficiente para filtrar e constranger decisões futuras que reflitam a mudança na correlação de forças trazida pela crise. Pode até limitar a emergência da hegemonia de outra fração do bloco no poder, prolongando uma situação de condomínio e divisão de poder que preserva sua

2 Para as empresas, a disciplina do mercado de capitais se expressou na doutrina gerencial da "maximização do valor acionário", sob o acicate da avaliação de resultados trimestrais na geração de lucros e distribuição de dividendos, e ênfase na inflação da cotação de ações (inclusive com recompra pela empresa) sob ameaça de aquisição hostil na bolsa de valores: ver Lazonick e Sullivan (2000), Lazonick (2012), Davis (2009) e Stout (2012). Tal doutrina gerencial significou, na prática, um aumento do poder estrutural do capital financeiro (bancos e investidores institucionais) sobre os outros stakeholders da empresa, como fornecedores, trabalhadores, a comunidade local e a fiscalidade, assim como, mutatis mutandis, a mobilidade internacional de capitais e a doutrina do regime de metas de inflação aumentaram seu poder estrutural na gestão da política econômica.

3 Weisbrot (2015). Para a hierarquia internacional das moedas, ver Conti e Prates (2016).

4 Para o conjunto de condicionalidades estruturais que foram impostas aos países asiáticos pelo governo dos EUA e pelo oligopólio financeiro de Wall Street, sob mediação do FMI, no que se convencionou chamar de "Consenso de Washington", ver Kapur e Webb (2000), Stiglitz (2003), Babb e Carruthers (2008) e Panitch e Gindin (2012). 
capacidade de extração de rendas financeiras, na dívida pública, na gestão da dívida interna e externa privada ou nos mercados de câmbio e de ativos diversos.

No contexto de crise cambial brasileira, a "blindagem institucional" reclamada por representantes do capital financeiro cristalizou regras neoliberais na política macroeconômica: o chamado novo “tripé macroeconômico" ou, a partir de 2012, de velha matriz econômica. Tal regime institucional caracteriza-se por i) livre mobilidade internacional de capitais com câmbio flutuante; ii) política monetária baseada no regime de metas de inflação (com elevação de taxa de juros, em tese, sempre que haja expectativa dos agentes do mercado financeiro de que a inflação vá superar o centro da meta); e iii) superavit primário estimado de modo que a economia de recursos fiscais compense, pelo menos em parte, os custos sobre a dívida pública associados à elevação de taxas de juros e à desvalorização cambial.

As novas regras foram justificadas explicitamente como meios de limitar a discricionariedade na execução da política econômica, com novas instituições e regimes legais que definem de antemão os raios de manobra dos futuros decisores de política econômica. Funcionam, portanto, como um filtro seletivo para as futuras políticas de governo, refletindo um determinado compromisso político característico de uma correlação prévia de forças que buscam consolidar.

É por isso que podemos falar, então, de um reforço do poder estrutural do capital financeiro, que se pode impor independentemente da resistência ou do consentimento ativo alheio, mesmo em situações de crise de hegemonia. Se a institucionalidade criada na crise não reflete, em sentido rigoroso, a hegemonia do capital financeiro, reforça seu poder estrutural para realizar uma ação contra-hegemônica, vetando a possibilidade de uma nova hegemonia instituir-se, com efeitos sobre a gestão da política macroeconômica.

Se seguirmos Nicos Poulantzas $(1968,1978)$ na definição do Estado capitalista como uma estrutura jurídico-política que assegura a dominação de classes, e a configuração de seus aparelhos concretos como a "condensação material de relações de forças sociais", segue-se que os aparelhos de Estado nos quais a luta entre classes e frações de classes opera não são um espaço "neutro" atravessado pelas lutas. A própria configuração das instituições de Estado condensa o resultado de lutas passadas, que inscrevem institucionalmente um poder próprio de frações de classe nos aparelhos materiais.

Assim, na própria institucionalidade do Estado está inscrita uma seletividade que filtra certos tipos de demanda e que se expressa não apenas no mandato jurídico dos diversos aparelhos, mas também nas relações que estabelecem (em reuniões e contatos mais ou menos rotineiros) com a clientela afetada diretamente por suas decisões, assim como na forma de recrutamento e socialização do pessoal de Estado talhado para cada aparelho. 
A defensiva em que se colocam os políticos e instituições de Estado com o mandato democrático de ampliar os níveis de investimento e emprego é reforçada quando a inflação e a dívida pública oscilam para cima, mesmo sem resultar de qualquer excesso de gasto público e sim de choques de alimentos, energia, de câmbio ou da própria taxa de juros. Esta é campeã disparada entre os países com mercados de capitais relevantes e é o principal motivo porque superavits primários enormes e privatizações entre 1991 e 2013 não foram capazes de "enxugar gelo" e mal reduziram o peso da dívida pública no orçamento (BASTOS, 2016a).

Dado o mandato institucional explícito no "tripé macroeconômico", o poder executivo sacramentado pelas urnas estará sempre sujeito à crítica (interna e externa ao aparelho de Estado) se a inflação se elevar e a reação do Banco Central não for a elevação de taxa de juros e a apreciação cambial, seguida de um esforço fiscal primário pelo Ministério da Fazenda para assegurar, com a austeridade dos cortes, a credibilidade da dívida pública perante os mercados financeiros.

Nos momentos em que a inflação ameaça reduzir juros reais, o poder estrutural do capital financeiro implícito no Tripé é complementado por uma grande ofensiva ideológica nos órgãos de opinião pública, aumentando o custo político do governo caso não se submeta logo nem consiga explicar técnica e claramente os motivos do problema inflacionário para a população ${ }^{5}$.

É inegável que, no Brasil, os economistas vinculados direta ou indiretamente a bancos e outros gestores de fundos aplicados na dívida pública defendem um patamar elevado de juros e de superavit fiscal primário, além de elevações frequentes desse patamar. São eles que são consultados pelo boletim FOCUS, que avalia as expectativas de inflação que guiam o regime de metas do BC, órgão no qual participam de reuniões periódicas, para o qual oferecem diretores e de onde contratam ex-diretores. Também é difícil negar que eles têm acesso privilegiado à opinião pública por meio dos principais meios de comunicação (PULITI, 2013). Isso é importante porque as convenções coletivas não são a mera somatória das opiniões individuais, sendo formadas em condições de forte assimetria de poder e reputação entre formadores e imitadores de opinião (LAVOIE, 2014).

\footnotetext{
5 Nas palavras de Antônio Gramsci: "O que se chama de 'opinião pública' está estreitamente ligado à hegemonia política, ou seja, é o ponto de contato entre a 'sociedade civil' e a 'sociedade política', entre o consenso e a força. O Estado, quando quer iniciar uma ação pouco popular, cria previamente a opinião pública adequada, isto é, organiza e centraliza certos elementos da sociedade civil... a opinião pública como hoje se entende nasceu às vésperas da queda dos Estados absolutistas, isto é, no período de luta da nova classe burguesa pela hegemonia política e pela conquista do poder. A opinião pública é o conteúdo político da vontade política pública, que poderia se discordante: por isto, existe luta pelo monopólio dos órgãos de opinião pública - jornais, partidos, Parlamento -, de modo que só uma força modele a opinião e, portanto, a vontade política nacional, desagregando os que discordam numa poeira individual e inorgânica" (GRAMSCI, 2000, Vol. 3, p. 265).
} 
A importância desse poder estrutural, inclusive na formação das convenções coletivas, pode ser avaliada na prática, como veremos, quando tal poder foi ameaçado no governo Dilma Rousseff.

\section{O MODELO DE CRESCIMENTO E SUAS RESTRIÇÕES}

Uma coisa é fazer um recuo tático diante de uma situação econômica vulnerável, de modo a acumular forças para sair da defensiva. Outra, bem pior, é passar a acreditar no sacrifício e em suas recompensas terrenas. A leitura "austérica" da política econômica de 2003 é que, tendo provado o travo amargo da austeridade, o governo Lula restaurara a confiança na solvência do Estado que os investidores precisavam para que o país voltasse a crescer.

A contradição do argumento é que o Brasil não gozara de estabilidade quando FHC foi forçado por uma crise financeira a abraçar o tripé macroeconômico e elevar taxas de juros básicas até mais do que $40 \%$. Meirelles prescreveu menor dosagem do mesmo remédio, e, com tamanha vantagem para as aplicações financeiras, não haveria "fada da confiança" que fizesse o investimento produtivo puxar a retomada do crescimento, ao invés de ser puxado pelo crescimento de outros itens de demanda, como de fato foi.

Se não foi o investimento empresarial que puxou o crescimento, o que permitiu a retomada do PIB em 2004, que por sua vez elevou receitas tributárias e retirou a dívida pública da trajetória explosiva em que FHC a havia deixado?

Primeiramente, em última instância, a economia brasileira foi abarrotada de reservas cambiais e literalmente "puxada" pelo novo modo de expansão da economia mundial marcado pela sinergia entre Estados Unidos e a Ásia. Em 2003, o comércio mundial estagnou, antes de crescer perto de $15 \%$ a.a. pelos cinco anos seguintes, mas as exportações brasileiras para os EUA e União Europeia já dobravam em relação a 2002 e decuplicaram em relação a 2001.

Também se iniciou em 2003 o boom das exportações industriais para a América do Sul e o boom das exportações de commodities para a China. No centro do comércio multilateral, a China ajudou-nos a despeito de nossos altos superavits fiscais e juros, seja importando commodities brasileiras, seja estimulando outros países sul-americanos que tinham juros e superavit primário muito menores e que cresciam mais que o Brasil, e com os quais tivemos grandes superavits comerciais puxados por exportações industriais. Nem tudo resultou de sorte, pois a promoção das exportações era um elemento essencial da cooperação Sul-Sul que passou a caracterizar a diplomacia brasileira sob comando de Celso Amorim e Samuel Pinheiro Guimarães (BASTOS, 2012a). 
Ademais, nenhum observador bem-intencionado ganha ao deixar de reconhecer o conjunto de políticas que melhoraram a distribuição de renda e incentivaram a expansão do mercado interno brasileiro. De fato, embora atendesse às exigências dos credores da dívida pública na condução do tripé da política macroeconômica, o governo Lula cometeu três heresias em relação ao neoliberalismo. Primeiro, vetou novas privatizações e, ao contrário, buscou restaurar a capacidade de investimento das empresas estatais, particularmente no setor de petróleo, gás e energia elétrica. Isso estimulou o ramo de bens de capital, construção naval e grandes empreiteiras, consolidando politicamente o apoio à frente neodesenvolvimentista das frações empresariais do que o sociólogo Armando Boito (2012a, 2012b) denomina de burguesia interna. A frente neodesenvolvimentista se constituiu como uma reação ao avanço global do capital estrangeiro e a retração do investimento estatal propostos pela frente neoliberal, liderada pelo PSDB $^{6}$.

$\mathrm{Na}$ segunda heresia, também contra a prática da frente neoliberal durante o governo FHC, o governo Lula restaurou o papel ativo dos bancos públicos para execução de políticas de desenvolvimento produtivo e expansão do mercado interno. O BNDES deixou de apoiar consórcios privados e fundos de pensão em programas de privatização, acelerando a expansão do crédito para investimentos em nova capacidade

6 "Burguesia interna" é um conceito proposto pelo sociólogo Nicos Poulantzas (1974) que designa frações do grande capital nacional unificadas pela "reivindicação de favorecimento e de proteção do Estado na concorrência que elas empreendem com o capital estrangeiro" (BOITO, 2012a, p. 7). Não se confunde com a antiga burguesia nacional (que em vários países participou de uma aliança com camadas populares contra o imperialismo) e se distingue da burguesia associada, "uma grande burguesia perfeitamente integrada e subordinada ao capital estrangeiro" (BOITO, 2012b, p. 71), cujos interesses são fortemente interligados à expansão do capital estrangeiro no país e demandam uma conexão pouco regulamentada dos mercados nacionais na "globalização". As características da frente neodesenvolvimentista seriam as seguintes, segundo Boito (2012a, p. 4-5): “a) essa frente é dirigida pela grande burguesia interna brasileira; b) tal frente envolve classes trabalhadoras que se encontram excluídas do bloco no poder - baixa classe média, operariado, campesinato e trabalhadores da massa marginal; c) a frente entretém uma relação de tipo populista com essa massa marginal; d) a frente se constituiu no principal recurso político do qual se valeu a grande burguesia interna para ascender politicamente no interior do bloco no poder e e) ela enfrenta, no processo político nacional, aquilo que poderíamos denominar o campo neoliberal ortodoxo, campo esse que representa - essa é a nossa hipótese de trabalho - o grande capital financeiro internacional, a fração burguesa brasileira perfeitamente integrada e subordinada a esse capital, setores dos grandes proprietários de terra e a alta classe média, principalmente aquela alocada no setor privado, mas também no setor público". Na caracterização de Boito, a frente neodesenvolvimentista não rompe com a inserção subordinada no capitalismo neoliberal global, e por isso "a) apresenta um crescimento econômico que, embora seja muito maior do que aquele verificado na década de 1990, é bem mais modesto que aquele propiciado pelo velho desenvolvimentismo, b) confere importância menor ao mercado interno, posto que mantém a abertura comercial herdada de Collor e de FHC c) atribui importância menor à política de desenvolvimento do parque industrial local, d) aceita os constrangimentos da divisão internacional do trabalho, promovendo, em condições históricas novas, uma reativação da função primário-exportadora do capitalismo brasileiro, e) tem menor capacidade distributiva da renda e f) o novo desenvolvimentismo é dirigido por uma fração burguesa que perdeu toda veleidade de agir como força social nacionalista e anti-imperialista" (BOITO, 2012a, p. 6). 
produtiva, infraestrutura e para a formação de conglomerados nacionais capazes de controlar cadeias globais de valor e competir com os grandes grupos multinacionais. Os bancos públicos comerciais, BB e Caixa, expandiram o crédito para agricultura (comercial e familiar), construção civil e pequenas e médias empresas, além de apoiarem os programas de crédito consignado que elevaram substancialmente o crédito para consumo no Brasil, contribuindo para a grande expansão do mercado interno (MARCOLINO e CARNEIRO, 2010; JAYME JR e CROCCO, 2010; IPEA, 2011).

Terceiro, o crescimento do mercado interno de massas foi apoiado pela política salarial, trabalhista e social que, respectivamente: i) elevou o salário mínimo real em $70 \%$ entre 2004 e 2014, com impacto no mercado de trabalho e nas pensões e aposentadorias do sistema de seguridade; ii) fortaleceu sindicatos e exigiu a formalização do emprego, com salários e direitos melhores, incluído o seguro desemprego; iii) ampliou o conjunto de transferências sociais, notadamente o Bolsa Família, o Benefício de Prestação Continuada e o bônus salarial, e recuperou o gasto na oferta de serviços públicos (CASTRO, 2012; BARBOSA, 2013; POCHMANN, 2013, 2014).

Tudo isso provocou o inverso do que as reformas neoliberais provocavam no mundo inteiro: a ampliação da participação dos assalariados na renda nacional, com grande ampliação do mercado consumidor de bens duráveis, serviços e imóveis, além de alguma melhoria das condições de trabalho. Esse perfil distributivo teve nítido efeito sobre o estilo de crescimento. Ao invés de iniciar a expansão estimulada pela "fada da credibilidade" da austeridade, o investimento e o consumo privado reagiram, primeiro, à expansão das exportações determinada pela recuperação mundial e, em seguida, acompanharam a massa salarial, as transferências sociais, o crédito consignado e os programas de infraestrutura (CARNEIRO, 2010; SERRANO e SUMMA, 2012; BIELSCHOWSKY et al., 2014; MEDEIROS, 2015).

Não obstante as três heresias, sua convivência com o tripé macroeconômico, ou melhor, a convivência entre os grupos da frente neodesenvolvimentista com o rentismo tinha contradições que ficaram ainda mais claras depois da crise global de 2008:

i) A liderança mundial em taxas de juros básicas pelo BCB (dentre os mercados de capitais relevantes) condicionou a apreciação cambial e implicou alto custo de rolagem da dívida pública interna, impedindo que ela caísse mais rápido, em relação ao PIB, a despeito do superavit primário verificado desde 1998 e do crescimento acelerado do PIB depois de 2005 (BASTOS, 2016a).

ii) A apreciação cambial, por sua vez, teve impacto sobre a competitividade da produção local que implicou vazamentos dos estímulos do crescimento do mercado interno sobre as decisões de produção e investimento, contribuindo para que se perdessem novos elos das cadeias produtivas (sobretudo depois da 
crise de 2008), para que não fossem reintegradas as cadeias produtivas perdidas na década de 1990 nem, muito menos, que fossem criadas novas cadeias na eletroeletrônica e química fina (AREND, 2015; MORCEIRO, 2016).

iii) O custo fiscal da política monetária exigiu a obtenção de altos superavits fiscais primários que diminuíam o espaço fiscal para atender simultaneamente às demandas de expansão do gasto social, do investimento público e da oferta de subsídios ao investimento privado, de modo que a infraestrutura social e de bens públicos avançava menos rapidamente do que os mercados de bens de consumo, serviços e habitação, o que se retratava, por exemplo, na duração dos congestionamentos de trânsito nas grandes cidades ou no aumento da demanda por escolas e plano de saúde privados (BASTOS, 2012b).

iv) O compromisso com metas fiscais rígidas, que normalmente prevêem superavits primários (dada a regra de ouro da Lei de Responsabilidade Fiscal), não é uma virtude: privilegia o interesse curto-prazista dos credores independentemente da necessidade de incorrer em deficit em certas circunstâncias em que a demanda privada não é capaz de sustentar o crescimento, exatamente para evitar uma elevação da relação dívida pública/PIB provocada por uma estagnação ou recessão do PIB. Ou seja, blindam institucionalmente uma política fiscal neoliberal marcada por forte componente pró-cíclico, o que é especialmente grave em momentos de desaceleração cíclica.

Ademais, se a aliança com representantes do capital financeiro implicou no elevado custo fiscal das decisões do Banco Central, a própria aliança com representantes da burguesia interna limitava novas elevações da carga tributária. Limitava, mais ainda, reformas na estrutura tributária fortemente regressiva que deslocassem a carga mais para a taxação do patrimônio e da renda das camadas sociais mais ricas (enfatizando seu papel redistributivo) e diminuíssem a sensibilidade da arrecadação ao crescimento econômico (que reforçava o caráter pró-cíclico do regime fiscal). Enquanto o governo procurava mitigar conflitos com os empresários e evitava mobilizar sua base social e eleitoral para confrontos públicos, organizações e representantes empresariais mantinham a iniciativa para criticar, forçar o governo a recuos ou levá-lo a derrotas parlamentares. A propósito, basta lembrar que o mesmo presidente da FIESP que defendeu Lula no episódio do Mensalão (Paulo Skaf) foi quem liderou o movimento para barrar a renovação da CPMF em 2007, voltando à carga em $2015^{7}$.

\footnotetext{
A FIESP mantém site sobre a campanha contra a CPMF e sua cronologia (Disponível em: <http:://www. fiesp.com.br/contra-a-cpmf/>), assim como o faz Paulo Skaf (Disponível em: <http://www.pauloskafoficial.com.br/skaf-contra-cpmf/>).
} 
Tudo isso implica que, em uma situação de desaceleração do crescimento econômico e da arrecadação de impostos, a preservação de uma meta nominal elevada para o superavit fiscal primário exige cortes de gastos que i) aumentam o conflito em torno de reivindicações de uso de recursos públicos e ii) diminuem a receita do setor privado, podendo acentuar a desaceleração dos gastos privados e, portanto, da própria arrecadação pública ${ }^{8}$.

Por outro lado, se as necessidades de acomodar reivindicações conflitivas sobre recursos públicos e/ou realizar uma política contracíclica levarem a uma diminuição (ex ante ou ex post) da meta de superavit primário, tal diminuição só evita um aumento significativo da relação dívida pública/PIB caso a taxa de juros caia e, no médio prazo, a desaceleração do PIB se reverta graças à política contracíclica e/ou uma melhoria das exportações líquidas. É claro que a pressão para redução da taxa de juros e para redução do custo fiscal da dívida pública será contrarrestada, no embate pela opinião pública, pelos intelectuais orgânicos do capital financeiro, sejam economistas dos bancos ou não, sobretudo se a inflação oscilar para cima, mesmo que por causa de alguma pressão de custo (sem relação com uma pressão de demanda agregada que possa ser contida com nova elevação de juros).

Tamanhas reivindicações conflitivas sobre recursos públicos ocorreram, na prática, porque a própria frente política neodesenvolvimentista tinha uma dinâmica interna contraditória, que foi reforçada pelo ciclo econômico (BASTOS, 2012b). Quais os vetores da contradição?

Primeiro, as demandas por salários maiores e melhores condições de trabalho tendiam a crescer à medida que a taxa de desemprego diminuía, os sindicatos se fortaleciam, o salário mínimo aumentava, o Ministério do Trabalho pressionava pela formalização de contratos, a Justiça do Trabalho dava ganhos de causa a reclamações

8 Formulei o problema desta maneira em Bastos: "Ao longo do governo Lula, a execução desigual de algumas dessas demandas de expansão do gasto social, do crédito e do investimento público sustentaram o fortalecimento do mercado interno, embora tenham entrado em choque também com metas de superávit primário definidas pelo Ministério da Fazenda... Não parece mais haver margem de manobra econômica, orçamentária e cambial, para realizar políticas desenvolvimentistas sem alterar as rotinas de política macroeconômica, e até parte da institucionalidade que regula suas interações com interesses privados. Na verdade, as próprias margens de manobra política podem se estreitar, em vista do choque entre prioridades de gasto social e em investimentos, elevados serviços da dívida pública, e solicitações de gasto oriundas da ampla base partidária do governo Dilma, venham ou não na forma de emendas parlamentares (oriundas de solicitações legítimas ou ilegítimas). De fato, um efeito colateral da multiplicação de demandas sobre uma arrecadação tributária líquida que cresce a taxas decrescentes é a proliferação de conflitos do governo com sua ampla base de apoio. Uma vez que a grande composição de interesses operada pelo governo Lula (a despeito do superávit primário) parecia ter como condições orçamentárias o rápido crescimento da arrecadação tributária, e as fases iniciais da recuperação do salário mínimo e do investimento público, a 'faxina' operada por Dilma em gastos ministeriais e emendas parlamentares parece, de certo modo, também reagir a uma restrição econômica" (2012b, p. 797 e p. 804-805). 
trabalhistas, jovens adiavam a entrada no mercado de trabalho, algumas mães saíam dele, enquanto a experiência de ganhos ampliava expectativas de novas conquistas ${ }^{9}$.

Embora o aumento dos salários estimulasse a demanda agregada e induzisse investimentos, empresários específicos tinham certeza quanto à elevação de custos trabalhistas, mas não quanto à captura de parcelas de mercado diante de rivais que podiam ter custos (inclusive trabalhistas) menores, até mesmo no exterior. Consequentemente, eles tendem a exigir mais moderação salarial e/ou corte de impostos, o que sempre foi um ponto de conflito na frente neodesenvolvimentista, mas que se aprofundaria ao longo do tempo. Se a reação do governo for desonerar tributariamente a folha salarial, veste um santo para desvestir outro, ou seja, renuncia arrecadação necessária para atender a reivindicações conflitivas sobre o orçamento público (se mantida a meta de superavit primário).

Segundo, o próprio crescimento econômico tendia a aumentar a pressão por investimentos públicos para superar pontos de estrangulamento de oferta manifestos pela retomada da demanda. Também aumentava a demanda por subsídios aos investimentos privados, seja por causa do maior risco do investimento de longo prazo de maturação e amortização na infraestrutura econômica, seja por causa do aguçamento da concorrência internacional trazido pela crise global no caso dos ramos ameaçados por importações, seja por causa da pressão por condições iguais de tratamento que tendem a generalizar subsídios imaginados para setores prioritários ${ }^{10}$.

O aumento endógeno da pressão por recursos para investimentos públicos e subsídios aos investimentos privados se chocava com demandas também crescentes por gastos sociais, à medida que os movimentos sociais por educação, saúde e habitação ampliavam a influência política e liberavam ambições, represadas até o primeiro governo Lula ${ }^{11}$.

9 Para os avanços e limites do sindicalismo e das conquistas trabalhistas no período, ver Baltar e Krein (2013), Boito, Galvão e Marcelino (2015), Braga (2016), Krein e Biavaschi (2015) e Galvão (2016).

${ }^{10}$ Isso ficou claro, por exemplo, quando o governo Dilma propôs desonerar a folha de pagamentos para quatro ramos de atividade no Plano Brasil Maior e estendeu a desoneração para 25.

${ }^{11}$ Como perdão da longa citação da explicação apresentada em Bastos (2012b): "É verdade que a retomada do crescimento em 2005 foi favorecida pela elevação do piso salarial, ampliação do gasto social e inovações financeiras (crédito consignado e microcrédito). É, contudo, improvável que esses efeitos dinâmicos iniciais, observados durante a fase de criação ou forte expansão de políticas redistributivas, possam ser repetidos indefinidamente, sustentando a longo prazo a estratégia de desenvolvimento. Isso exigiria graus de liberdade inexistentes no orçamento fiscal e da seguridade social... A própria ativação de um círculo virtuoso entre redistribuição de renda e expansão do mercado interno de massas pressiona os estrangulamentos da estrutura produtiva e logística e, dadas as descontinuidades de escala de oferta, exige a expansão dos investimentos adiante da demanda corrente. Com isso, surgem pressões sobre o orçamento fiscal que concorrem com novas solicitações redistributivas sobre o gasto social. Essa concorrência é pequena nos estágios iniciais de expansão do investimento público (e dos subsídios ao investimento privado), mas tende a agravar-se com o tempo... Mesmo dentro dos governos petistas, parece haver grupos mais 
Tais reivindicações conflitivas, por sua vez, destinavam-se à colisão com os limites colocados pelo tripé macroeconômico: por que não reduzir juros e o custo fiscal da política monetária para aumentar o espaço fiscal destinado para outras reivindicações?

\section{O GOVERNO DILMA ROUSSEFF: ASCENSÃO E QUEDA DA NOVA MATRIZ ECONÔMICA}

Dilma Rousseff foi eleita em 2010 no contexto de uma economia que se recuperava com êxito dos efeitos da crise financeira global de 2008 e em um cenário de grande otimismo. Embora seu projeto de governo não fosse explicitado na campanha, seu objetivo principal logo ficaria claro: senão eliminar, minimizar o rentismo com a dívida pública como meio sistemático de acumulação de capital. Isso significa questionar o poder estrutural do capital financeiro na determinação das taxas de juros e câmbio, rompendo o pacto conservador formado pelo governo Lula em 2003. Isso seria uma grande mudança estrutural (BASTOS, 2012b).

A radicalidade desse plano foi mascarada porque o governo o tratou de modo relativamente tímido, sem fazer uma ampla campanha pública dos argumentos técnicos que justificavam sua posição, em uma disputa pela hegemonia da interpretação convencional perante a opinião pública. O governo tampouco se preparou para o embate público no momento da reação dos interesses ameaçados, que foi capaz de se apresentar como meramente técnica e não como profundamente política, usando o controle dos meios de comunicação para dominar a narrativa e taxar o governo de "irresponsável tecnicamente" e "politicamente populista"12.

Ao reduzir juros e, portanto, o custo fiscal da dívida pública, o governo tinha três objetivos: i) ganhar graus de liberdade fiscal para a execução da política social, de

favoráveis do que outros à elevação dos salários diretos e indiretos a um ritmo superior ao crescimento do gasto público ou do PIB, embora em conjunto sejam favoráveis a um patamar mais alto do que a corrente do desenvolvimentismo exportador. $\mathrm{O}$ equilíbrio de poder entre os grupos no interior da corrente distributiva pode variar, inclusive, em razão dos diferentes desafios colocados pela conjuntura. É inegável, por exemplo, que haja um conjunto vasto de políticas orientadas para a elevação do investimento, e alguma moderação do ritmo de expansão do gasto social e dos aumentos salariais no governo Dilma. De fato, além da defesa da ação redistributiva do Estado, a corrente é favorável ao papel do Estado para realizar, financiar ou coordenar um conjunto de grandes projetos de investimento que não se resume a oferecer condições gerais para a acumulação de capital (como infraestrutura, educação básica e superior, saúde, ensino técnico etc.), mas que passa gradualmente a envolver-se na reestruturação de setores prioritários. Uma coisa não se harmoniza facilmente com a outra: alguém duvida que, a curto prazo, operações de capitalização dos bancos públicos, ou ampliações dos subsídios a investidores privados, possam opor-se a elevações do gasto social?” (BASTOS, 2012b, p. 795-796).

12 Esse plano, aliás, foi apresentado no final de 2011 em várias declarações de Guido Mantega (2012) e Marcio Holland (2012a, 2012b), o secretário de política econômica do Ministério da Fazenda, que o batizaram de Nova Matriz Econômica (NME). 
investimento público e subsídios aos investimentos privados; ii) ao reduzir a rentabilidade das aplicações financeiras do setor privado com risco mínimo, forçar a ampliação do investimento produtivo e em infraestrutura, apoiando-o com subsídios fiscais e creditícios; ii) reduzir o diferencial internacional de juros e, assim, criar condições para a depreciação cambial, entendida como necessária para conferir competitividade internacional aos investimentos produtivos.

Em suma, o governo propunha mudar a relação entre orçamento público e patrimônio privado, reduzindo transferências financeiras para portadores da dívida pública, mas aumentando transferências em subsídios (diretos e indiretos) para apoiar investimentos em formação de capital fixo. Com isso, o uso do espaço fiscal para subsídios aumentaria vis-à-vis o investimento público.

O cerne do plano era, portanto, mudar os preços relativos que induziam decisões de investimento privado, colocando-o no protagonismo da estratégia de desenvolvimento. Nada menos do que modificar três décadas de rentismo curto-prazista e deslocar capitais em larga escala para investimento de longo prazo em infraestrutura e diversificação industrial. Com isso, assegurar o crescimento do emprego, a geração de receitas tributárias e a redução da vulnerabilidade externa.

Em outras palavras, do ponto de vista da implementação econômica, o plano envolvia três preços essenciais: taxa de juros básica, taxa de câmbio e taxa de lucro do investimento privado na infraestrutura e na indústria de transformação:

i) Queda da taxa de juros: o objetivo era reduzir a atratividade de aplicações em títulos da dívida pública pelas empresas não financeiras e reduzir seu custo para capital de giro e financiamento do investimento produtivo à medida que os bancos públicos acompanhassem o Banco Central e reduzissem o spread e a taxa de juros final para os empréstimos de curto e longo prazo.

ii) Aumento da taxa de câmbio (preço do dólar em reais): o objetivo da desvalorização cambial era aumentar a competitividade internacional da produção local no mercado interno e nas exportações, induzindo investimentos produtivos, sobretudo na indústria de transformação.

iii) Aumento da taxa de lucro: usar o espaço fiscal liberado pela redução do custo financeiro da dívida pública para reduzir custos do investimento privado com oferta pública de subsídios creditícios, fiscais e trabalhistas, e redução de preços administrados de serviços e insumos essenciais, como tarifas rodoviárias, aeroviárias e portuárias, energia elétrica e combustíveis.

Qual o resultado da aplicação dessa estratégia? Divido a discussão nos planos econômico e político, começando com o primeiro. 
Economicamente, a execução foi prejudicada por iniciar com uma primeira fase de austeridade que supostamente prepararia as condições para a queda dos juros, e que estagnou o PIB entre o segundo semestre de 2011 e o primeiro de 2012. Em seguida, a execução da NME atenuou, sem reverter, a desaceleração cíclica da economia apenas a partir do segundo semestre de 2012, mas começou a ser abandonada no segundo trimestre de 2013.

O problema da estratégia, portanto, é que, antes mesmo de reduzir o custo de capital, ela deprimiu as expectativas de demanda futura. Isso não foi um resultado da NME, mas sim da desaceleração cíclica e do aguçamento sem precedentes da "velha matriz econômica" em 2011.

A primeira fase de contenção foi iniciada logo depois da eleição de Dilma Rousseff, em novembro de 2010, quando o governo Lula iniciou um novo ciclo de elevação de taxas de juros e elevação de impostos sobre o consumo que não apenas foi continuado no primeiro semestre do governo Rousseff, mas reforçado com a chamada regulação macroprudencial operada pelo BC, ou seja, os limites quantitativos para a expansão do crédito. A meta de juros Selic subiu de $8,75 \%$ para 9,50\% em abril de 2010, daí até $10,75 \%$ entre julho e dezembro de 2010 , alcançando o pico de $12,5 \%$ entre 21 de julho e 31 de agosto de 2011, enquanto uma série de medidas "macroprudenciais" limitava a expansão do crédito ${ }^{13}$.

Ademais, a política fiscal foi fortemente contracionista em 2011. Em valores reais (de 2015), o superavit primário aumentou R\$ 56 bilhões entre 2010 e 2011, ou 1,28\% do PIB. As receitas cresceram à taxa de 5,4\% em 2010 e de 8,1\% em 2011, mas as despesas cresceram à taxa de 6,1\% em 2010 e apenas $1,7 \%$ em 2011 . O crescimento das despesas foi pequeno, mas ainda assim mascara o tamanho da austeridade e a mudança no perfil do gasto público. Em termos reais, o investimento público caiu 13,4\% (ou $\mathrm{R} \$ 8,6$ bilhões), o gasto com pessoal caiu $0,7 \%$, o gasto em custeio nada cresceu e o investimento das empresas estatais caiu 8,6\%. Entretanto, os subsídios aumentaram $35 \%$, ou R\$ 11,2 bilhões, sendo R\$ 9,3 bilhões para o programa Minha Casa Minha Vida. Entre 2011 e 2014, o padrão foi seguido: o investimento público cairia 1,1\% a.a., mas os subsídios aumentaram $23,8 \%$ a.a. ${ }^{14}$.

${ }^{13}$ Segundo Prates e Cunha (2012), tais medidas foram: a) aumento do deposito compulsório sobre depósitos bancários; b) aumento do capital mínimo requerido para empréstimos ao consumidor de prazos mais longos, como financiamento de automóveis; c) aumento dos impostos sobre operações financeiras para o crédito ao consumidor; e d) aumento do percentual mínimo de pagamento de saldos de cartões de crédito. Ver Serrano e Summa (2012) para a apreciação crítica da primeira fase do governo Rousseff.

${ }^{14}$ A ideia era que a contração fiscal de 2011 era necessária para reduzir os juros, como admitiu o ministro Guido Mantega (2012): "foi muito importante a elevação do resultado primário de 2011 para dar respaldo à redução de juros”. Em setembro de 2013, Mantega fez autocrítica e justificativa da fase de austeridade: "Fizemos o aperto em 2011 supondo que a economia mundial já estava em recuperação. Em 2011 pu- 
Em setembro de 2011, finalmente o BC iniciou ciclo de redução das taxas de juros, mas a estagnação do PIB prosseguiu por quatro trimestres, recuperando-se apenas no último semestre de 2012. A reversão da austeridade fiscal em 2012, de fato, foi tímida e sem comunicação adequada de seus objetivos. O investimento público, por exemplo, não compensou a queda de $13,4 \%$ em 2011 e aumentou 3,7\% em 2012, voltando a cair $6,1 \%$ em 2013.

Outro elemento da NME era a desvalorização cambial para aumentar a competitividade industrial. A política cambial também teve duas fases: i) manter a apreciação cambial para controlar a inflação e ii) reverter e monitorar o processo de correção da taxa de câmbio, sem deixá-lo inteiramente para o mercado, para impedir uma espiral especulativa de depreciação do Real.

De início, a elevação da taxa de juros teve por efeito aumentar a apreciação cambial, levando a taxa a sair de 1,87 em fevereiro de 2010, 1,73 em novembro de 2010 e oscilar em R \$ 1,50-1,60/US\$ entre maio e julho de 2011, contribuindo para o controle da inflação com a queda do preço dos produtos importados. Em seguida, a primeira iniciativa para reverter a apreciação cambial foi a regulação da especulação nos mercados futuros e a elevação de impostos sobre entrada de capitais de curto prazo, tendo o mesmo efeito de uma redução do diferencial internacional de juros (PRATES, 2015; ROSSI, 2016).

A segunda foi a própria queda da taxa de juros. A redução foi iniciada em setembro de 2011 e concluída em outubro de 2012, levando a SELIC de 12,5\% a.a. para $7,25 \%$, onde ficou até abril de 2013. Isso reduziu ainda mais o diferencial internacional de taxas de juros e a atração de recursos para aplicações em títulos públicos no Brasil. A desvalorização do câmbio comercial do Real começou em agosto, até que a faixa de oscilação se estabilizasse em R\$2,00-2,10 entre maio de 2012 e maio de 2013.

Uma nova rodada de depreciação cambial ocorreu em maio de 2013, diante dos rumores de mudança da política monetária nos EUA. Esses rumores, a elevação da inflação e a pressão do mercado financeiro, como veremos, colocaram pressão para que o BC abandonasse a política monetária que favorecera a depreciação cambial pretendida pelo governo. Afinal, os problemas agora eram i) evitar que a desvalorização cambial saísse de controle e ii) limitar sua transmissão para a inflação. Para o primeiro problema, a resposta do BC foi iniciar novo ciclo de elevação de juros em abril de 2013 e oferecer swap cambial a partir de agosto de 2013, o equivalente à venda de dólares no mercado futuro, limitando o impacto da demanda de dólares sobre a taxa cambial corrente.

xamos o freio, dizendo: a gente faz um ajuste e depois retoma. Só que quando foi retomar, no segundo semestre de 2011, já tinha começado a crise europeia... Em 2011, quando achamos que a crise já tinha passado, todos os países tinham ido bem em 2010 e o Brasil cresceu 7,5\%. Então, fizemos um ajuste mais forte, um superavit (fiscal) mais forte e um ajuste monetário maior, o que desacelerou fortemente (a economia). Se eu soubesse que, no segundo semestre de 2011 teríamos a crise europeia eclodindo, talvez tivéssemos usado uma mão mais leve" (ALVES et al., 2013). 
Para o segundo problema, a resposta contou com a política fiscal como política anti-inflacionária, mas não mais em linha com a interpretação do "novo consenso", talvez porque a inflação experimentada fosse sobretudo de custos e não, dada a desaceleração cíclica, de demanda excessiva. De fato, o governo ampliou subsídios tributários e creditícios, além de subsídios implícitos na política de alguns preços administrados, como derivados de petróleo. Ademais, aproveitou a conclusão dos contratos de concessão de energia elétrica para negociar a redução da taxa de retorno de investimentos amortizados para concessionárias que preferissem permanecer no negócio, deixando em aberto a opção de realizar novo leilão ao fim dos contratos vigentes caso as concessionárias monopolistas não aceitassem a redução dos preços.

Além de mitigar o impacto inflacionário da depreciação cambial, a oferta de subsídios tributários e creditícios e a redução de preços administrados foram justificadas como meio de recuperar a competitividade que a apreciação cambial e o fortalecimento da "fábrica asiática" deprimira. Isso é evidente no Plano Brasil Maior, anunciado em agosto de 2011, que reforçaria os objetivos da NME. Ou seja, o custo de conter o impacto inflacionário da depreciação cambial e de reforçar a competitividade privada foi trazido para as contas públicas.

O governo parecia ter confiança nas mudanças de preços relativos: juros mais baixos, correção cambial, isenções tributárias e subsídios teriam o condão de sustentar o investimento nos ramos de bens comercializáveis, enquanto as concessões estimulariam o investimento em infraestrutura. Desse modo, o investimento privado assumiria o protagonismo na sustentação do crescimento, em conjunto com os investimentos da $2^{a}$ fase do Programa de Aceleração do Crescimento (PAC 2) e das empresas estatais, principalmente da Petrobras no pré-sal.

Ademais, um programa de encomendas governamentais vincularia o investimento público ao privado, com fornecedores da cadeia do petróleo, equipamentos militares, suprimentos de comunicação e hospitalares. Ao mesmo tempo, barreiras comerciais e exigências de conteúdo nacional estimulariam o investimento direto externo na automobilística (Inovar-Auto e acordo bilateral com o México) e eletroeletrônica, como na atração da Foxconn em acordo com o governo da China.

De fato, o conjunto de alterações de preços relativos era significativo: desonerações tributárias e previdenciárias, reduzindo o custo de bens de capital e de contratação de mão-de-obra; crédito subsidiado dos bancos públicos; redução da taxa SELIC; início da correção da taxa de câmbio; incentivos fiscais para o lançamento de debêntures de longo prazo; barateamento de preços administrados de insumos essenciais ${ }^{15}$.

15 Essas alterações, aliás, eram objeto explícito de demandas das associações representativas dos industriais, em conjunto com sindicatos trabalhistas, naquilo que foi batizado de movimento "Por um Brasil Com Juros Baixos: Mais Produção e Emprego” desde outubro de 2011 (FIESP, 2011). Não é possível dizer que 
Em parte por causa da desaceleração da demanda, e em parte por causa do vazamento da mesma para importações, a produção industrial permaneceu praticamente estagnada no nível de 2008 a despeito do conjunto de incentivos, depois da recuperação em 2009 e 2010. Ou seja, a mudança de preços relativos não teve sucesso em induzir, em termos agregados, a produção e o investimento privado na indústria de transformação. $\mathrm{O}$ controle de preços administrados, a desoneração da folha salarial e a queda dos juros (até abril de 2013) não parecem ter mitigado a pressão sobre as margens unitárias em virtude do encarecimento de passivos externos, insumos e equipamentos importados trazidos pela depreciação cambial, enquanto a desaceleração da demanda e seu vazamento para importações praticamente estagnou quantidades produzidas. Como resultado, a taxa de lucro da indústria de transformação caiu entre 2011 e 2014.

O vazamento da demanda interna para importações deve ser entendido no contexto da superprodução de capacidade ociosa trazido pela Grande Recessão. Ela acelerou a queda dos preços industriais, deprimiu rentabilidade e provocou mudanças estruturais na distribuição da produção e do comércio na indústria mundial. A Ásia em desenvolvimento e, em particular, a China, praticamente dobrou a produção industrial e aumentou muito sua participação no mercado global, enquanto a produção industrial só recuperou o patamar pré-crise nos EUA em meados de 2013, não tendo alcançado esse patamar ainda no Japão e na Europa. O esforço exportador estadunidense e europeu também aumentou à medida que tais países buscavam sair da crise buscando mercados externos ainda em expansão no mundo periférico, particularmente na América do Sul, também invadida por exportações industriais asiáticas que fugiam da desaceleração da demanda no mundo desenvolvido (BASTOS, 2012a, 2012b, 2015d).

Como resultado, a parcela da demanda interna brasileira de manufaturados atendida por importações aumentou, ao mesmo tempo em que as exportações industriais perdiam mercado seja na América do Sul, seja nos mercados de origem das matrizes controladoras das filiais da indústria de transformação. Tudo indica a ocorrência de uma redistribuição da produção no interior das corporações globais, em benefício da produção nos mercados em crise onde também se localizavam os centros de propriedade e comando das corporações. A posição da filial sul-americana nas cadeias glo-

fossem opções autônomas de técnicos dissociados da sociedade e do mundo dos interesses. A hipótese de autonomia tecnocrática é a opinião dos bons textos de Nobre (2016) e Pinto (2016), mas não a de Singer (2015). Mais do que autonomia na definição do projeto em si, que claramente se articulou a reivindicações públicas da FIESP, o estilo executivo da presidenta Dilma Rousseff parece ser caracterizado, de acordo com vários relatos públicos e pessoais, pela baixa capacidade de diálogo e articulação e excesso de verticalidade decisória, refletidos, por exemplo, na aversão a conversas com políticos, empresários e lideranças sindicais, e na desmobilização do Conselho de Desenvolvimento Econômico e Social (CDES). 
bais de valor foi redimensionada, tornando-se menos produtora e mais importadora, montadora e revendedora. Isso se reflete na grande mudança nos saldos comerciais brasileiros, particularmente com os países de origem das filiais aqui localizadas.

Tabela 1 - Brasil: Saldo comercial com regiões e países selecionados (em US\$ milhões)

\begin{tabular}{|r|r|r|r|r|r|r|r|r|r|}
\hline Ano & EUA & $\begin{array}{c}\text { União } \\
\text { Europeia }\end{array}$ & $\begin{array}{c}\text { América } \\
\text { do Sul }\end{array}$ & $\begin{array}{c}\text { Mercosul } \\
\text { - }\end{array}$ & $\begin{array}{c}\text { Mercosul } \\
\text { Argentina }\end{array}$ & China & $\begin{array}{c}\text { Coreia } \\
\text { do Sul }\end{array}$ & México \\
\hline 2000 & 290 & 833 & 245 & -631 & -56 & -605 & -136 & -856 & 958 \\
\hline 2001 & 1.303 & 78 & 990 & -286 & -635 & -1.196 & 573 & -837 & 1.175 \\
\hline 2002 & 5.090 & 2.141 & -136 & -2.127 & -2.293 & -2.397 & 966 & -214 & 1.765 \\
\hline 2003 & 7.158 & 5.806 & 2.516 & 332 & -919 & -102 & 2.385 & 144 & 2.214 \\
\hline 2004 & 8.742 & 8.754 & 6.444 & 3.815 & 2.544 & 1.821 & 1.730 & -300 & 3.254 \\
\hline 2005 & 9.873 & 8.888 & 10.503 & 6.660 & 4.692 & 3.689 & 1.480 & -430 & 3.231 \\
\hline 2006 & 9.867 & 10.918 & 11.787 & 7.992 & 5.018 & 3.686 & 411 & -1.143 & 3.147 \\
\hline 2007 & 6.341 & 13.824 & 13.388 & 10.106 & 5.728 & 4.012 & -1.872 & -1.344 & 2.281 \\
\hline 2008 & 1.795 & 10.403 & 14.224 & 11.414 & 6.803 & 4.347 & -3.521 & -2.279 & 1.155 \\
\hline 2009 & -4.430 & 4.950 & 7.893 & 5.750 & 2.721 & 1.503 & 5.092 & -2.160 & -107 \\
\hline 2010 & -7.737 & 4.172 & 11.257 & 9.002 & 5.981 & 4.087 & 5.190 & -4.661 & -143 \\
\hline 2011 & -8.165 & 6.708 & 14.355 & 11.802 & 8.476 & 5.802 & 11.523 & -5.403 & -1.171 \\
\hline 2012 & -5.661 & 1.386 & 9.644 & 7.608 & 3.549 & 1.553 & 6.976 & -4.597 & -2.071 \\
\hline 2013 & -11.350 & -2.975 & 9.224 & 9.083 & 5.414 & 3.152 & 8.722 & -4.771 & -1.564 \\
\hline 2014 & -7.979 & -4.669 & 6.900 & 6.607 & $3.149,16$ & 138 & 3.271 & -4.694 & -1.693 \\
\hline
\end{tabular}

Nota: Mercosul 5 inclui Venezuela.

Fonte: Elaboração própria com base em dados de MDIC.

\section{Tabela 2 - Brasil: Variação do saldo comercial com regiões e países selecionados (2007 vs. 2014) (em US\$ milhões)}

\begin{tabular}{|c|c|c|c|c|c|c|c|c|c|}
\hline Ano & EUA & $\begin{array}{c}\text { União } \\
\text { Europeia }\end{array}$ & $\begin{array}{c}\text { América } \\
\text { do Sul }\end{array}$ & $\begin{array}{c}\text { Mercosul } \\
\mathbf{- 5}\end{array}$ & $\begin{array}{c}\text { Mercosul } \\
\mathbf{- 4}\end{array}$ & Argentina & China & $\begin{array}{c}\text { Coreia } \\
\text { do Sul }\end{array}$ & México \\
\hline $2007-2014$ & -14.321 & -18.494 & -6.488 & -3.500 & -2.580 & -3.875 & 5.143 & -3.349 & -3.974 \\
\hline
\end{tabular}

Nota: Mercosul 5 inclui Venezuela.

Fonte: Elaboração própria com base em dados de MDIC.

A queda do investimento industrial agregado só não foi maior por causa da cadeia de petróleo e gás, por conta do pré-sal, e da expansão da capacidade na indústria automobilística, à medida que as empresas se antecipavam para ocupar o mercado futuro em meio à chegada de novos produtores asiáticos no mercado brasileiro e às exigências do programa Inovar-Auto. Como resultado do boom de investimento no maior ramo na indústria brasileira, o potencial produtivo foi o dobro da produção em 2014, ao mesmo tempo em que a importação de automóveis aumentava no contexto da superprodução global de capacidade ociosa, o que deprimiria fortemente os investimentos a partir de 2014 . 
Tabela 3 - Brasil: Saldo comercial de autoveículos com regiões e países selecionados (em US\$ milhões)

\begin{tabular}{|l|l|l|l|c|c|c|c|}
\hline Ano & Mundo & México & $\begin{array}{c}\text { União } \\
\text { Europeia }\end{array}$ & EUA & $\begin{array}{c}\text { Coreia do } \\
\text { Sul }\end{array}$ & Japão & China \\
\hline 2006 & 4687,1 & 1193,5 & 250,1 & 191,4 & $-37,1$ & $-116,9$ & 10,4 \\
\hline 2007 & 3716,8 & 539,3 & 409,2 & 1,2 & $-339,5$ & $-182,9$ & 7,3 \\
\hline 2008 & 1544,3 & $-219,8$ & 438,6 & $-108,9$ & $-816,2$ & -324 & $-116,9$ \\
\hline 2009 & -2350 & $-414,1$ & $-16,5$ & $-90,8$ & $-1057,8$ & $-205,8$ & $-85,4$ \\
\hline 2010 & $-3959,9$ & $-524,5$ & $-834,8$ & $-138,6$ & $-1912,7$ & $-337,5$ & $-215,4$ \\
\hline 2011 & $-7052,6$ & $-1546,1$ & $-1950,9$ & $-196,5$ & $-2436,5$ & $-645,9$ & $-761,5$ \\
\hline 2013 & $-5916,7$ & $-2194,9$ & $-1351,5$ & $-113,7$ & $-1195,9$ & $-534,3$ & $-181,5$ \\
\hline
\end{tabular}

Fonte: Elaboração própria com base em dados do Anuário da Indústria Automobilística Brasileira (ANFAVEA, 2015).

Tabela 4 - Brasil: Variação do saldo comercial de autoveículos com

\begin{tabular}{|c|c|c|c|c|c|c|c|}
\hline Ano & Mundo & México & $\begin{array}{c}\text { União } \\
\text { Europeia }\end{array}$ & EUA & $\begin{array}{c}\text { Coreia do } \\
\text { Sul }\end{array}$ & Japão & China \\
\hline $2006-2014$ & $-10086,7$ & $-2529,4$ & $-1903,2$ & -435 & $-511,1$ & $-297,1$ & $-166,6$ \\
\hline
\end{tabular}

Fonte: Elaboração própria com base em dados do Anuário da Indústria Automobilística Brasileira (ANFAVEA, 2015).

A despeito da estagnação do investimento industrial, a taxa de investimento em relação ao PIB se manteve quase estável em 20\% do PIB entre 2010 e 2014, porque o investimento privado autônomo em construção civil e infraestrutura aumentou mais do que o PIB, compensando a queda do investimento industrial e a retração do investimento público em transportes e aeroportos, por exemplo. Em transportes, o investimento público caiu de $\mathrm{R} \$ 18,5$ bilhões em 2010 para $\mathrm{R} \$ 13,2$ bilhões em 2013, mas o investimento privado passou de $\mathrm{R} \$ 9,5$ bilhões para $\mathrm{R} \$ 16,2$ bilhões, mantendo o total de R $\$ 29$ bilhões entre 2010 e 2013. Em aeroportos, a soma do investimento público e estatal (Infraero) caiu ligeiramente até 2014, mas o investimento privado saiu do zero em 2010 para tornar-se três vezes maior que o investimento público em 2013.

Por que, então, a economia desacelerou de novo em 2014?

Primeiro, porque o ciclo longo de ampliação do consumo e do investimento residencial desacelerou. Não é possível dizer que isso resultou de um boicote dos bancos, pois os bancos privados só retraíram o crédito para aquisição de automóveis, enquanto o sistema de bancos públicos ganhou participação ao longo de todo o período posterior à crise financeira global e podia continuar expandindo crédito se houvesse demanda. Acontece que o nível de endividamento e comprometimento da renda das famílias subiu, acompanhando o atendimento da demanda reprimida por bens de consumo duráveis, automóveis de passeio e, agora, terrenos e residências. Se o medo do desemprego levasse as famílias a desalavancar, ou seja, pagar dívidas ao invés de 
contratar novas, enquanto o medo da inadimplência e a elevação dos juros básicos levasse os bancos a cortar crédito pessoal, a reversão do ciclo de crédito para consumo e imóveis poderia ser grave. Isso não ocorreu em 2014, porém.

A desaceleração cíclica de 2014 foi reforçada pelo impacto do ciclo de elevação de taxas de juros iniciado em abril de 2013 depois da elevação do estoque de dívidas com imóveis e bens duráveis, encarecendo sua rolagem. O consumo das famílias continuou desacelerando para crescimento de 2,3\% em 2014 (3,5\% em 2012 e 3,6\% em 2013), sobretudo para bens de mais alto valor agregado, apesar do aumento de $4,1 \%$ da massa salarial real. $\mathrm{O}$ crédito com recursos livres para pessoas físicas decresceu em termos reais (cresceu nominalmente 5,5\% para inflação IPCA de 6,41\%), refletindo o esgotamento da demanda reprimida por automóveis. É difícil alegar que houve boicote bancário, pois o crédito pessoal com recursos livres ainda cresceu 11,1\% (desacelerando do crescimento de 14,7\% em 2013), de modo que a queda resultou da contração do crédito para aquisição de automóveis, que caiu 4,5\% (já contraíra 0,2 em 2013). O crédito com recursos direcionados, contudo, cresceu $24,9 \%$, sendo que o crédito imobiliário (quase $70 \%$ do total e $234 \%$ maior que o crédito para aquisição de automóveis) cresceu 24,9\%. Com isso, o crédito total para pessoas físicas ainda cresceu 13,3\% (BCB, 2015). Dada a concentração dos empréstimos para investimento residencial, o comércio sofreu queda real de 1,8\%. Como o consumo tem um peso de $62,5 \%$ no PIB, a desaceleração cíclica impactou fortemente na desaceleração da renda e do emprego, a despeito do impacto favorável da construção civil. A taxa de desocupação aumentou de 6,5\% em 2013 para 6,9\% em 2014, segundo a PNAD-IBGE.

Além desse determinante cíclico, dados do cadastro (CAGED) do Ministério do Trabalho mostram que a estrutura do mercado de trabalho se deteriorou ao longo da desaceleração, tendo o mercado gerado (liquidamente) empregos exclusivamente abaixo de 1,5 salário mínimo em 2013 e 2014 (e apenas até dois salários mínimos em 2011 e 2012), com impactos significativos sobre a capacidade de endividamento das famílias em cenário de forte aumento da rotatividade. Segundo a PNAD-IBGE, o ramo que paga melhores salários, a indústria de transformação, chegou a ocupar 13,1 milhões de trabalhadores em 2008 (14,5\% do total de empregos), partindo de 8,2 milhões em 1999 (11,6\% do total de empregos) e 10,6 milhões em 2002 (13,7\% do total de empregos), mas caiu para 12 milhões em 2013 e 2014 (12,7\% e 12,4\% do total de empregos).

Segundo, em 2014 as exportações caíram 7\% em valor e 1,8\% em quantum (12,9\% para manufaturados apesar da desvalorização cambial), puxadas pelo comportamento da demanda externa e dos preços das commodities. A reversão dos termos de intercâmbio já ocorria desde 2011: o crescimento anual superior a 4\% entre 2004 e 2011 foi seguido de uma redução pouco inferior a 4\% a.a. desde setembro de 2011, mas se 
agravou em setembro de 2014. Isso só teria impacto grave na indústria de extração mineral em 2015, pois esta ainda acumulou crescimento de 8,7\% em 2014.

Ademais, as exportações de manufaturados sofreram indiretamente com a deflação das commodities por conta da crise de seus principais mercados na América do Sul. Nesses mercados declinantes, como vimos, as exportações brasileiras enfrentaram a concorrência crescente de exportações chinesas e dos países de origem das filiais instaladas no Brasil. A perda de participação nos mercados em desaceleração na América do Sul ajuda a explicar o declínio do entusiasmo da indústria brasileira e, em particular, da FIESP em relação à integração comercial sul-americana valorizada pelos governos liderados pelo PT, e o elogio de acordos bilaterais extrabloco valorizados pelo PSDB que, supostamente, integrariam melhor a indústria brasileira nas cadeias globais de valor ${ }^{16}$.

Terceiro, os investimentos em construção civil, na infraestrutura e na cadeia de petróleo e gás também sofreram uma desaceleração cíclica. Na construção civil, porque a elevação de preços de imóveis desacelerou o ciclo de endividamento para aquisição e construção residencial das famílias, ao mesmo tempo em que a oferta de imóveis novos abarrotava o mercado e deprimia novos investimentos. Na infraestrutura, porque os principais leilões na logística rodoviária, ferroviária e aeroportuária, assim como as obras de mobilidade urbana e estádios para a Copa do Mundo, já haviam sido realizados até 2013, enquanto obras em portos ficaram em compasso de espera dos embates sobre a regulação do ramo e do resultado das eleições presidenciais. O problema é que um novo conjunto de obras em infraestrutura, particularmente em saneamento e mobilidade urbana (um tema central às jornadas de junho de 2013), não foi planejado em tempo para suceder os projetos apresentados em 2010 que amadureciam.

No setor de petróleo e gás, a reversão era mais grave por causa da importância da Petrobras e do pré-sal no investimento global e na geração de recursos parafiscais para o financiamento da infraestrutura de educação, ciência e tecnologia. Tanto a queda dos preços internacionais do petróleo quanto a Operação Lava-Jato se iniciaram em abril de 2014, tendo impacto grave sobre os linkages de renda, arrecadação fiscal e demanda interindustrial nas economias de Rio de Janeiro, Espírito Santo, Bahia e São Paulo ao longo do ano. Teriam efeitos ainda mais graves sobre o investimento em

16 Não há espaço aqui para discutir a demanda de um novo realinhamento externo do Brasil por parte crescente do empresariado, explicada por Bastos e Hiratuka (2017) pela desaceleração e crise da América do Sul, pelo aprofundamento dos conflitos sociais nos países "bolivarianos" dos quais a burguesia e a alta classe média brasileiras preferem se afastar, pela ameaça de isolamento em relação às "parcerias" transcontinentais que os EUA buscaram negociar com a Europa e a Ásia, e pela possibilidade de blindar o neoliberalismo internamente através desses tratados transcontinentais, no que tange às relações de trabalho e intervenções regulatórias indevidas, mas não necessariamente subsídios. Para os dois primeiros determinantes, ver Beringer (2016). 
infraestrutura em razão da paralisia das grandes construtoras ao longo de 2015, reforçando o efeito negativo do aumento brutal dos preços de energia elétrica e insumos básicos antes controlados.

A despeito dos fatores de desaceleração cíclica evidentes em 2014, a economia brasileira cresceu $0,5 \%$ no ano. Os primeiros dados apresentados pelo IBGE indicaram crescimento de $0,1 \%$, com crescimento no primeiro trimestre e forte queda no segundo (quando ocorreram os feriados e a queda da procura de carros e imóveis durante a Copa do Mundo), seguida de recuperação nos trimestres seguintes. A despeito disso, os economistas que previam, no final de 2014, que a execução do programa de cortes liderado por Joaquim Levy levaria a um crescimento econômico de 0,8\% em 2015 não admitiram o erro de suas previsões, preferindo alegar que a recessão começara em 2014. De modo inconvincente, desrespeitavam inteiramente o entendimento convencional de que uma recessão exige não apenas uma queda excepcional em um trimestre, mas pelo menos dois trimestres seguidos de queda, o que não ocorreu em 2014. A revisão dos dados de 2014 pelo IBGE em novembro de 2016 mostraria crescimento de $0,5 \%$ e não $0,1 \%$, sem levar à autocrítica daqueles que revisavam o passado para preservar reputações e não admitir o fracasso da austeridade expansionista que propunham pelo menos desde 2013, de modo a poder continuar propondo mais do mesmo.

\section{A RESISTÊNCIA DO CAPITAL FINANCEIRO E AS ORIGENS DA UNIFICAÇÃO BURGUESA}

O recuo do governo Dilma diante da reação dos interesses rentistas atingidos pela guerra dos juros começou quando o Banco Central iniciou novo ciclo de elevação da taxa de juros em abril de 2013.

Como vimos, a existência dos regimes de metas de inflação e de metas de superavit primário conferia um enorme poder estrutural para o capital financeiro. Se eventualmente a inflação subisse e o Banco Central não elevasse a taxa de juros, era sujeito ao bombardeio midiático contra a suposta interferência política em sua autonomia operacional. Se eventualmente a arrecadação tributária desacelerasse e o gasto primário não seguisse a mesma direção, o governo era atacado por não cuidar da credibilidade da trajetória da dívida pública nem da própria inflação.

Por isso, uma modificação na forma de gestão das políticas monetária e fiscal não podia passar por uma "flexibilização" timidamente explicada, mas sim por uma transformação do próprio regime institucional, ancorada em uma ampla campanha pública pela hegemonia da interpretação técnica e convencional perante a opinião pública. Como isso não foi feito, a reação dos representantes ideológicos do capital financeiro apresentou-se como meramente técnica e não como profundamente política, recor- 
rendo ao controle de meios de comunicação para taxar o governo de "irresponsável tecnicamente" e "politicamente populista", deslegitimando o ataque de Dilma Rousseff aos banqueiros e colocando-a na defensiva. De fato, Dilma não só abusou de pronunciamentos que pareciam querer jogar a população contra os bancos comerciais ou cortar o elo político entre o capital bancário e outras frações da burguesia, mas recorreu a uma política agressiva de ocupação de mercado por bancos públicos que lideraram a redução de juros nos empréstimos pessoal e empresarial.

$\mathrm{O}$ argumento ortodoxo favorável ao aumento da taxa de juros era pouco convincente, pois a elevação da inflação no início de 2013 resultou de choques de custos e não do sobreaquecimento da demanda. Circunstancialmente, as pressões de custos resultaram da depreciação cambial, do choque de preços agrícolas e da elevação dos fretes vinculada, sobretudo, a normas ambientais para caminhões (BASTOS e ROSSI, 2013).

Uma pressão mais estrutural era a tendência de elevação dos preços de serviços intensivos em trabalho, resultando da formalização do emprego e da elevação do salário mínimo, que ainda baliza a escala de remunerações desses serviços. Ademais, há uma tendência de elevação dos preços de serviços intensivos em trabalho acima da média em razão da transmissão do aumento de salários dos ramos de maior produtividade para esses serviços, nos quais a produtividade cresce muito menos. O economista William Baumol (1967) batizou isso de "doença de custos" dos serviços e mostrou que ela ocorre em todas as economias capitalistas de modo estrutural. Isto é, não resulta de um sobreaquecimento da economia determinado por excesso conjuntural de demanda que deva ser contido pela elevação de taxas de juros demandada pelos economistas do setor financeiro, muito embora a doença possa ser reforçada circunstancialmente pela formalização de contratos e pela elevação do salário mínimo (BASTOS, 2015d) ${ }^{17}$.

Dois fatores econômicos podiam justificar a elevação de juros, embora não necessariamente na escala ocorrida. Primeiro, a queda anterior dos juros básicos foi tão pronunciada que qualquer aumento da inflação podia ameaçar reduzi-los para patamares próximos de zero. Segundo, tamanha redução é inviável se o governo quiser controlar o ritmo de depreciação cambial, sobretudo se houver a possibilidade de elevação de taxa de juros nos países centrais, já que o Banco Central não complementou controles nos mercados futuros contra a apreciação cambial com controles contra a depreciação (ROSSI, 2016).

17 Pesquisa do Datafolha (2013) indicou que serviços domésticos tipicamente contratados pela alta classe média tiveram inflação em São Paulo muito superior ao IPC-Fipe (31\%) entre 2008 e 2013: babá (102\%), caseiro em São Paulo (89\%), caseiro no interior/litoral (80\%), faxineira/lavadeira/passadeira (66\%), motorista particular (61\%), auxiliar de enfermagem (54\%), empregada doméstica (51\%), diferentes tipos de pintura (cerca de $110 \%$ ), colocação de revestimento em parede (80\%) e colocação de piso (59\%). Sobre prováveis reações políticas a tal redistribuição de renda, ver Cavalcante (2015). 
Embora o argumento ortodoxo fosse frágil, a pressão dos bancos não era. Segundo o chefe de pesquisas para Mercados Emergentes das Américas da Nomura Securities, Tony Volpon, o mercado financeiro teve sucesso ao "pressionar" o Banco Central, senão mesmo apoiá-lo contra o desejo do governo: o BC não apenas iniciou um novo ciclo de elevação de taxas de juros em abril de 2013, mas o estendeu graças ao alarme sobre os riscos de depreciação do Real trazidos pela possibilidade de interrupção do programa de facilitação quantitativa do FED nos EUA. Em 22 de setembro de 2014, Volpon admitiu que, diante da perspectiva de reeleição de Dilma Rousseff, o mercado financeiro agiria de modo coordenado para impor-lhe o "pragmatismo sob coação", como fez em 2013:

A visão otimista é que, uma vez que a eleição acabe, Rousseff sabe que precisa comprometer-se com os mercados e ser mais pragmática... Nossa visão atual é que, provavelmente, só veremos uma mudança real na política econômica em um segundo governo Dilma sob pressão substancial do mercado. O modelo para nós é exatamente o ciclo de aperto feito pelo BC em 2013, que só alcançou a extensão que teve por causa das pressões criadas pela discussão em torno do "tapering" do Fed. Chamaríamos isso de "pragmatismo sob coação". (VOLPON, 2014, p. 1-2)

A retórica neoliberal alarmista foi tão onipresente que parece ter contaminado expectativas inflacionárias, particularmente aquelas registradas no boletim Focus do BC junto aos analistas de mercado financeiro que, aparentemente, estavam dedicados à arte do "pragmatismo sob coação". Até mesmo Fernando Henrique Cardoso chegou a explicar os protestos de junho por causa da elevação de preços no primeiro semestre de 2013 e da expectativa de que se acelerariam (LIMA, 2013).

Embora tivesse solicitado ativamente a redução dos juros, a FIESP se colocou em postura passiva perante o ataque contra a política de juros baixos que antes pedira. Por quê?

$\mathrm{O}$ argumento de que a financeirização do capitalismo e a formação de grupos multifuncionais aboliu inteiramente a distinção entre frações do capital não é convincente, porque a FIESP e várias organizações empresariais apoiaram a redução da taxa de juros em 2011 (e o capital bancário não). Podemos cogitar três hipóteses que não exigem tamanha fusão, mas que admitem alguns interesses comuns, a depender das conjunturas, em torno de juros elevados para títulos da dívida pública.

Primeiro, empresas não bancárias também dispõem de aplicações financeiras que, em tese, podem compensar a queda de rentabilidade dos investimentos produtivos, sobretudo sempre que as vendas caiam quando os juros aumentam. Dessa vez, contudo, a estratégia de diversificação não oferecia segurança, porque o ritmo de vendas e a taxa de juros caíam juntos, gerando pressões simultâneas sobre a lucratividade 
industrial e financeira. Para empresas com saldos ociosos que não encontram oportunidades de investimento produtivo por causa da conjuntura incerta ou recessiva, não há melhor subsídio público do que poder aplicá-los em títulos da dívida pública com juros elevados e risco nulo.

Segundo, parecia haver o interesse de barrar o avanço político de uma presidente que cometeu o pecado de politizar e mobilizar apoio popular, por exemplo, em declarações públicas no Primeiro de Maio de 2012 sobre uma questão distributiva essencial para uma fração do capital, que sempre pareceu terreno da neutralidade técnica: afinal, depois do ataque público aos spreads bancários, quem seria o próximo a sofrer um ataque "arbitrário" do governo? Ou seja, a solidariedade de classe contra a intervenção estatal "populista" voltada ao "macro gerenciamento" de margens de lucro setoriais pode ter tido importância aqui.

A terceira hipótese é que há empresas que não precisam de juros baixos nos bancos comerciais, pois não dependem de empréstimos privados, tendo fundos líquidos ou acesso prioritário ao crédito público subsidiado. Afinal, melhor do que ter acesso a subsídios creditícios é tê-los exatamente quando os juros dos títulos públicos oferecem bons ganhos de arbitragem, como parte do empresariado aprendeu com a "ciranda financeira" patrocinada por Mário Henrique Simonsen nos anos 1970.

Do ponto de vista político, a elevação de juros significava um recuo cujo cálculo parecia ser o de mitigar o ataque dos interesses rentistas e seus representantes ideológicos. É nesse momento que o governo começa a tentar recompor o amplo bloco no poder manobrado por Lula, o que será reforçado em $2015^{18}$.

Isso traria novas contradições. Por um lado, a busca de governabilidade do bloco no poder pode prejudicar a popularidade do governo, contradição esta que também será reforçada em 2015. Por outro lado, isso implica reativar o bolsa-rentista sem desativar (a até ampliar) o bolsa-empresário, o que poderia, no futuro, criar problemas para o financiamento do Bolsa Família e do gasto social.

Além da guerra dos juros, um fator decisivo para a tendência de unificação da burguesia era a pauta de austeridade fiscal e salarial. Sem dúvidas há fatores culturais para isso, refletidos na opinião empresarial de que o Bolsa Família reduz a procura por empre-

${ }^{18}$ Em entrevista a Luis Nassif veiculada em 9 de junho de 2016, Dilma Rousseff relembra a pressão unificada pela elevação da taxa de juros: "Ali, a política tradicional do Banco Central começa uma pressão, uma pressão sob a taxa da inflação. Tanto que nós tentamos uma série de medidas para impedir que houvesse uma explosão, principalmente, dos preços administrados... Tem um grau de financeirização na economia brasileira, em que todos os setores têm interesses. Havia, e acho que isso ficou patente, uma grande resistência à queda da taxa de juros. Não era algo trivial. Inclusive, porque diziam que estavam afetando o valor das ações na bolsa. Havia, então, uma situação que era bastante diversa para, não só aqueles que atuam especificamente no setor financeiro, mas também na indústria em geral e no setor serviços" (FAERMANN, 2016). 
gos e dificulta a contratação, como se desconhecessem que o valor máximo do benefício é bem inferior ao salário mínimo e que quase metade dos beneficiários é de trabalhadores por conta própria. Walquíria Leão Rego e Alessandro Pinzani (2013) e Jessé Souza (2009, 2016) argumentaram que a persistência de uma cultura autoritária e a ideologia da meritocracia explicam a resistência a políticas públicas e movimentos sociais voltados à redução das desigualdades sociais genéticas do país. Pode-se cogitar que as sucessivas vitórias eleitorais de um programa orientado para mitigá-las aumentassem a resistência cultural, tanto mais se ela fosse estimulada por instituições, como o Instituto Millenium, que patrocinam intelectuais que têm ampla visibilidade nos meios de comunicação tradicionais e que culpam os aumentos salariais e os gastos sociais, equivocadamente, como o motivo da desaceleração do investimento privado e da redução dos lucros e da "poupança".

Análises dos custos e margens de lucro mostram, porém, que a lucratividade industrial cresceu bastante até 2010, quando o crescimento salarial foi maior, tornando pouco crível a hipótese de esmagamento de lucros provocado por salários excessivos. Às vezes se esquece que a renda de assalariados se transforma em lucros dos capitalistas frequentemente antes do fim do mês, tanto mais quanto o aumento salarial alça novos contingentes sociais ao mercado de consumo de massas e ao mercado de crédito bancário. É verdade que, a partir de 2011, o valor adicionado industrial deixou de crescer a despeito do crescimento da demanda interna em razão da avalanche de importações, inclusive por empresas industriais interessadas em revenda de bens importados. Mantido o bolo, a elevação da parcela dos salários no valor adicionado desde 2005, porém, foi tímida, de maneira que os gastos com salários e benefícios representam parcela pequena nos custos totais, ou apenas 14,2\% em 2012, mal tendo recuperado metade de sua queda entre 1996 e 2004 (HIRATUKA, 2015; ver Gráfico 1). Ademais, há evidências de que a desoneração da folha de pagamentos compensou parte importante do pequeno aumento do peso de salários nos custos totais (SCHERER, 2015).

\section{Gráfico 1 - Percentagem dos Gastos Totais com Pessoal no Valor da Transformação Industrial (1996 a 2012)}

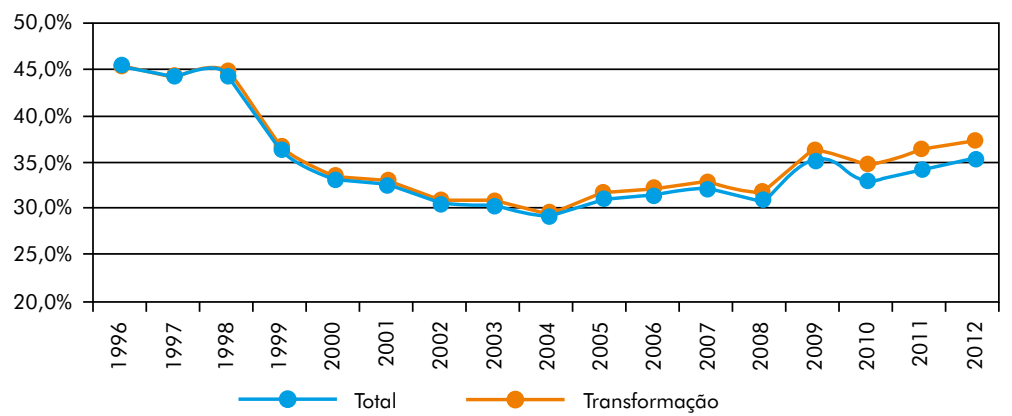

Fonte: Hiratuka (2015). 
Se os salários não são a causa fundamental da redução da rentabilidade, por que são o centro do ataque, talvez só rivalizando com a estrutura tributária, para além dos motivos políticos e culturais aludidos? Ora, porque mesmo que a compressão da margem de lucro não tenha sido provocada pela pressão salarial, o ataque aos salários e aos impostos é uma forma de saída empresarial típica. O projeto é limitar ou mesmo esmagar salários para compensar a queda no resultado e na margem operacional provocada pela pressão concorrencial global e por custos não vinculados à produção: aluguéis e rubricas em parte afetadas pelo encarecimento do dólar, como produtos para revenda, fretes, seguros, leasing, royalties e passivo financeiro.

\section{Gráfico 2 - Estrutura de custos na indústria de transformação: 1996 a 2012}

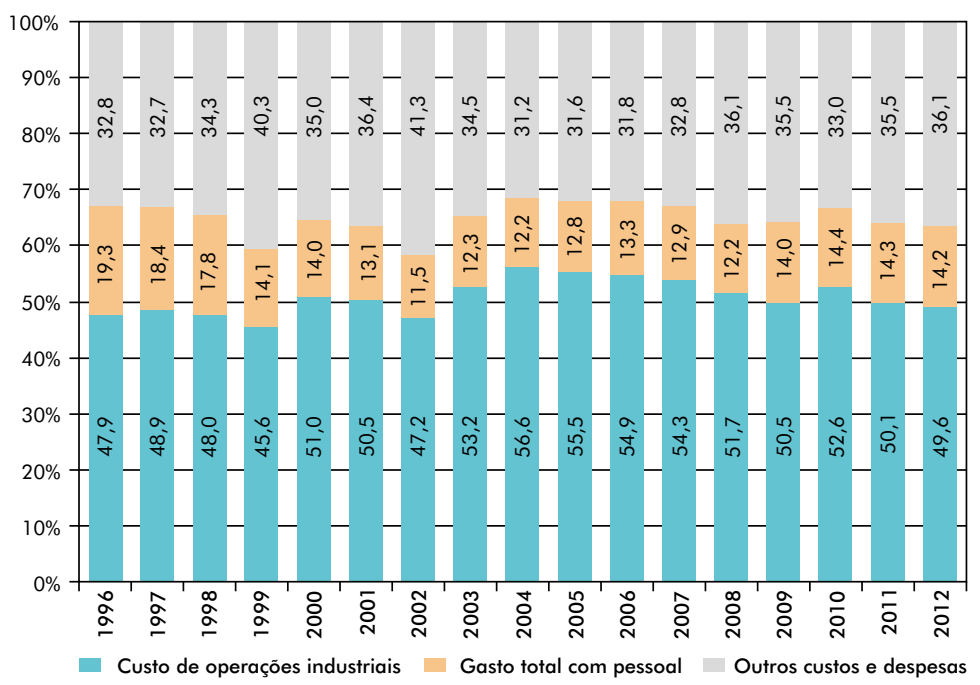

Fonte: Hiratuka (2015).

Ademais, dado o passivo externo das empresas e a dependência crescente por serviços, insumos e máquinas importados, assim como mercadorias para revenda, a desvalorização cambial não assegura em curto prazo nem aumento de exportações nem substituição de importações, mas pressiona margens operacionais. Ou seja, o encarecimento do dólar aumenta os custos das empresas sem garantir o aumento de suas receitas. Como mostra Diegues (2015), as margens de lucro na indústria se correlacionam negativamente com a taxa de câmbio desde a década de 1990, ou seja, caem quando a taxa de câmbio aumenta, isto é, quando o Real se deprecia em relação ao dólar. A desvalorização prejudica sua rentabilidade em vista da dificuldade de substituir bens e serviços importados em médio prazo, e mesmo em longo, sem políticas estruturantes e mesmo negociação com corporações multinacionais que monopolizam certas tecnologias mundialmente. 
Se comparados com os aluguéis e o custo de bens e serviços importados, os salários não são o principal fator a pressionar a rentabilidade das empresas depois da crise global, embora a demanda por sua "flexibilidade" seja um mecanismo tradicional de recomposição da rentabilidade microeconômica. Daí a demanda para o aumento do desemprego para reduzir salários e restaurar a disciplina sobre o trabalho que uma situação de desemprego decrescente tende a afrouxar (KALECKI, 1943; BASTOS, 2014a).

É, portanto, em um sentido preciso que a austeridade pode recuperar a "credibilidade" da política econômica perante empresários: não a credibilidade quanto à possibilidade de ganhar dinheiro com investimentos produtivos, mas a credibilidade do poder disciplinador da política econômica sobre os trabalhadores e sobre as expectativas dos beneficiários do gasto público. Com a austeridade, a política econômica restaura a "credibilidade" dos empresários de que os trabalhadores serão colocados "em seu devido lugar" com a ameaça crescente de desemprego; e que os beneficiários do gasto público reduzirão expectativas de novos benefícios em um cenário de sacrifício geral, deixando de pressionar para que novos gastos sejam financiados por novos impostos (MITERHOF, 2013; STREECK, 2014; SCHUI, 2014; RUGITSKY, 2015).

Isso ajuda a explicar porque os candidatos de oposição a Dilma em 2014, que prometiam a austeridade para conter os "excessos" trabalhistas do governo e defendiam as propostas da frente neoliberal, tiveram apoio ou ao menos, a "inação conivente" de frações da burguesia que ganharam com as políticas desenvolvimentistas de proteção do espaço nacional e regional de acumulação de capital contra a concorrência das corporações multinacionais. De fato, a questão salarial, os gastos sociais e a regulação trabalhista tendiam a alinhar as diferentes frações da burguesia contra os trabalhadores, mesmo que estes fossem a base social e eleitoral que apoiou a frente neodesenvolvimentista em sua fase de consolidação ${ }^{19}$.

\section{A REVOLTA DAS CAMADAS MÉDIAS E O ATAQUE POLÍTICO-JUDICIAL}

Além dos elementos imateriais relativos ao status social perante os "pobres", a questão dos salários de base é a principal questão distributiva que une o topo da frente neoliberal à sua base de massas. Essa base é a camada média com alguma qualificação profissional e educacional, especializada em trabalho não manual, e a pequena burguesia que, no Brasil, sempre gozaram de um padrão de vida semelhante aos de camadas médias de países de renda per capita superior porque contavam com bens e serviços

19 Essa contradição interna da frente neodesenvolvimentista lembra remotamente outros episódios da história brasileira entre 1943 e 1964, em que a questão social e trabalhista unificou a burguesia e a polarizou contra o "populismo", com apoio decisivo de camadas médias civis e militares: Boito (1982); Toledo (1984); Saes (1985a); Bastos (2004, 2012c, 2014c). 
barateados pelos baixos salários dos trabalhadores desqualificados e precários, muitos deles negros e mestiços (SAES, 1985a; CARDOSO DE MELLO e NOVAIS, 1998).

O governo Lula afetou seus interesses, uma vez que a redução da desigualdade parece ter se concentrado na redistribuição da renda entre trabalhadores pobres, de um lado, camadas médias e pequenos empresários, de outro. É verdade que a participação dos salários na renda caiu continuamente de 60,2\% em 1993 para 46,2\% em 2004, daí subindo até $51 \%$ em 2013 . No entanto, ocorreu estabilidade da desigualdade de renda em geral porque o topo da distribuição de renda, ou seja, os grupos entre $0,1 \%$ e $5 \%$ mais ricos absorveu parcela crescente da renda nacional entre 2006 e $2012^{20}$.

Ademais, a disputa por vagas por empregos típicos de classe média aumentou muito em 2013, quando esta classe retirou das ruas o quase monopólio que as esquerdas tinham desde 1978 e que ainda se verificou nos primeiros dias das jornadas de junho. Segundo Waldir Quadros (2015), com base na PNAD, o número de miseráveis aumentou 1,3 milhão no Brasil e 321 mil em São Paulo entre 2012 e 2013. As ocupações com rendimentos de baixa classe média aumentaram, mas a alta classe média diminuiu em 780 mil pessoas no Brasil e 204 mil em São Paulo, enquanto a média classe média encolheu 2,6 milhões no Brasil e 1,4 milhão em São Paulo ${ }^{21}$.

\section{Tabela 5 - Estrutura de rendimentos no Brasil e em São Paulo (2012-2013; em mil pessoas)}

\begin{tabular}{|l|c|c|c|r|r|r|r|}
\hline Padrões de vida & $\mathbf{2 0 1 2}(\mathbf{B R})$ & $\mathbf{2 0 1 2}(\mathbf{S P})$ & $\mathbf{2 0 1 3}(\mathbf{B R})$ & $\mathbf{2 0 1 3}(\mathbf{S P})$ & $\Delta \mathbf{( B R )}$ & $\Delta(\mathbf{S P})$ \\
\hline Alta classe média & 17.877 & 5.347 & 17.097 & 5.143 & -780 & -204 \\
\hline Média classe media & 31.459 & 10.159 & 28.857 & 8.739 & -2.603 & -1.420 \\
\hline Baixa classe média & 86.658 & 22.475 & 89.043 & 23.609 & 2.385 & 1.133 \\
\hline Massa trabalhadora & 50.548 & 4.683 & 50.218 & 4.852 & -330 & 169 \\
\hline Miseráveis & 14.926 & 1.105 & 16.253 & 1.427 & 1.327 & 321 \\
\hline Total & 201.467 & 43.769 & 201.467 & 43.469 & 0 & 0 \\
\hline
\end{tabular}

Nota: Condensei as tabelas que retiram o efeito do crescimento populacional. Fonte: Quadros (2015).

${ }^{20}$ Isso não era captado pelas pesquisas domiciliares (PNAD), mas fica claro nas declarações de imposto de renda avaliadas por Medeiros et al. (2015). Os dados de participação dos salários na renda nacional são estimados por Saramago (2016). Agradeço ao professor Ricardo Summa (UFRJ) pela informação e envio da dissertação de Saramago.

${ }^{21}$ De acordo com outros estudos de Quadros (2010, 2014), a queda em 2013 foi a primeira desde 2003. Usei o termo "padrões de vida" do autor para designar a estrutura de rendimentos sem discutir as controvérsias teóricas que envolve, algumas das quais são abordadas pelo autor em vários textos. Outros estudos de Quadros $(1991 ; 2002)$ abordaram tanto o grande crescimento da classe média durante o Milagre econômico quanto à crise da reprodução dos empregos de classe média nas décadas de 1980 e, principalmente 1990, o que ajuda a explicar o deslocamento político de parte crescente das camadas médias contra o neoliberalismo e a favor do PT, pelo menos até 2005. Para a discussão dos processos políticos e ideológicos associados à crise da reprodução social da classe média nos anos 1990 em ampla perspectiva histórica, ver Cardoso de Melo e Novais (1998) e Cardoso (2010). Para pesquisas no âmbito do CESIT-UNICAMP sobre a estratificação social no Brasil, ver Cardoso (1999), Maia (2006), Remy (2008), Quadros e Maia (2010) e Horie (2012). 
É importante frisar que, em 2002, 468 mil alunos completaram as atividades de graduação, mas em dezembro de 2012 o número de formandos de ensino superior chegava a 1,05 milhão, ou seja, um aumento de 124\% que era apoiado por programas de inclusão social como o Prouni, o Fies e a política de cotas (INEP, 2010, p. 32; 2015, p. 63). A reprodução social da classe média tradicional sofria uma tensão significativa no momento de ofensiva ideológica e política da direita a partir da segunda fase das jornadas de junho de 2013, principalmente em São Paulo.

Além da disputa crescente por um número menor de empregos bem remunerados, as camadas médias tradicionais experimentaram ao longo do tempo mais concorrência por rede de infraestrutura (como aeroportos, rodovias e avenidas) e serviços (como educação e saúde) que consideravam exclusivos, experimentando perda de status social e ameaça à pretensão de distinção cultural (SICSÚ, 2014; CAVALCANTE, 2015). Também consideram que seus impostos pagam os benefícios sociais para os mais pobres e o presumido aparelhamento do Estado brasileiro por militantes socialistas e políticos corruptos, sem que o encarecimento do custo dos serviços privados seja compensado pela abundância de serviços públicos que, como dizia Fernando Haddad, não melhoravam como a vida da porta da casa para dentro (BASTOS, 2014a). Assim, o avanço do populismo de direita no Brasil contava com a revolta de camadas médias imprensadas pelo custo dos serviços privados, pela carência de empregos e pelo avanço dos de baixo, pelo qual culpavam o populismo e a demagogia dos políticos que compravam apoio popular com políticas sociais que elas custeavam, em um padrão discursivo muito parecido com aquele identificado por John Judis em sua pesquisa sobre o avanço do populismo nos Estados Unidos e na Europa em meio à Grande Recessão (JUDIS, 2016). ${ }^{22}$

Nesse contexto de avanço do populismo de direita no Brasil, é inegável que a revolta contra a corrupção confluiu com os demais focos de insatisfação das camadas médias tradicionais, assumindo centralidade. Paradoxalmente, a questão da corrupção foi manipulada para ajudar a derrubar um governo que contribuía para as investigações e colocar no poder um grupo político corrupto e interessado em barrar as investigações. A

22 A rejeição a políticas seletivas de inclusão social ficou clara em pesquisas de opinião com os manifestantes pró-impeachment em 2015. No que tange ao perfil de renda, inserção profissional e educação dos manifestantes, eles estavam acima da média da população brasileira em renda, participação de trabalhadores white collar e profissionais liberais, e educação superior. Na manifestação de 12 de abril de 2015 em São Paulo, a pesquisa coordenada por M. Cortês e P. Trópia (2015) pediu que os manifestantes escolhessem três entre quinze iniciativas dos governos do PT que mais os afetaram negativamente. Os mais indicados foram: Bolsa Família (44,5\%), Auxílio reclusão a famílias de detentos (43,7\%) e os programas de cotas raciais nas universidades públicas (35,6\%). Na manifestação de 16 de agosto de 2015 em São Paulo, a pesquisa coordenada por Pablo Ortellado et al. (2015b) atestou que 70,4\% dos manifestantes concordava (total ou parcialmente) com a afirmação de que "É justo quem estudou e se esforçou mais na vida tenha alguns privilégios" e 79,5\% com "Negros não devem usar a cor da pele para conseguirem privilégios como cotas raciais". 
rapidez das delações e dos vazamentos que prejudicavam o PT, com ampla divulgação midiática, contrasta com a delação e o vazamento tardio da compra de votos parlamentares pela Odebrecht, que prejudicaria os políticos que comandavam o impeachment no Congresso Nacional. Nesse sentido, é no mínimo ingênuo negar o uso político seletivo do combate à corrupção para finalidades particularistas, ou seja, destruir a reputação do PT e enfraquecer a popularidade da presidenta Dilma, criando condições para o golpe ${ }^{23}$.

A espetacularização midiática da corrupção também personalizou responsabilidades e, deliberadamente, não tematizou os arranjos estruturais do sistema político que contribuem para a corrupção (CHAUI, 2013). Ao que eu saiba, nenhuma das grandes empresas de mídia fez sequer um mero editorial pelo fim das contribuições empresariais para campanhas eleitorais, a raiz da corrupção no poder executivo e legislativo. Ainda que os problemas nas instituições políticas possam explicar parte da revolta contra o sistema político, o diagnóstico moralista implica propostas limitadas ao combate à corrupção que não tocam nos problemas da desproporcionalidade de representação regional legados pela ditadura (Pacote de Abril de 1977), a fragmentação partidária e o alto custo de campanhas pessoais (sem lista partidária ordenada) e da formação de maiorias parlamentares para assegurar a governabilidade da agenda legislativa, ou seja, os problemas associados tipicamente ao "presidencialismo de coalizão", assim como a baixa informação e participação da população com a política em uma sociedade de tradição autoritária e excludente.

Dado o uso político do combate à corrupção, é possível associar a ação de membros do sistema judiciário, do Ministério Público Federal (MPF) e da Polícia Federal (PF) contra os métodos corruptos do "presidencialismo de coalizão" como expressão da revolta política das classes médias e, em particular, da alta classe média?

A partir da crítica marxista da ideologia da meritocracia (o meritocratismo) e a partir do conceito de distinção de Pierre Bourdieu, Savio Cavalcante (2015), Armando Boito (2016a, 2016b) e Andreia Galvão (2016b) sugerem que sim, pelo menos indiretamente: a corrupção se choca com o meritocratismo que a classe média pratica no cotidiano (sincera ou hipocritamente) e que defende para legitimar sua posição na hierarquia social. O meritocratismo é a ideologia que legitima a diferenciação do prestígio e da remuneração de trabalhadores não manuais a partir da hierarquia de dons e

${ }^{23}$ Basta lembrar que alguns membros do aparelho judicial e coercitivo fizeram campanha política na internet por Aécio Neves em 2014, em favor da qual vazaram suposta delação de Alberto Yousseff usada pela revista Veja como panfleto eleitoral a três dias da eleição: Duailibi (2014). Um dos delegados da PF envolvidos na campanha eleitoral de 2014, Márcio Anselmo, foi responsável pelo indiciamento de Lula em agosto e em dezembro de 2016 (FÓRUM, 2016a, 2016b). Em 2016, o timing dos vazamentos, da condução ilegal de Lula ou de Guido Mantega e, em particular, da divulgação ilegal das conversas entre Lula e Dilma pelo juiz Sérgio Moro, além de sua convocação de protestos de massa na mesma semana, também evidenciam o uso político do processo judicial: Singer (2016a, 2016b, 2016c). 
méritos pessoais, sem contextualização das condições sociais que dividem e hierarquizam o trabalho intelectual e manual e que pré-estruturam o resultado da competição por empregos qualificados, ao diferenciar socialmente o acesso ao sistema escolar. No Brasil, o meritocratismo tem força especial por causa da desvalorização que séculos de escravidão impuseram ao trabalho manual, por causa da desigualdade histórica de acesso à educação e por causa da ameaça à reprodução das camadas médias colocada por crises de crescimento e por episódios de conflito distributivo em que é imprensada pela pressão dos de cima e dos de baixo ${ }^{24}$.

Boito (2016a), em particular, sugere que juízes, promotores e policiais federais não são quaisquer membros da alta classe média, mas encarnam a ideologia do mérito da ascensão pelo concurso público para assumir, como tarefa funcional-burocrática, a defesa da ordem legal universalista e a repressão ao crime, inclusive de desvio de recursos públicos. Exatamente por isso detêm prerrogativas políticas exclusivas (o que os aproximam das elites) e tendem a ser objeto de identificação e até adoração por parte da classe média que se revolta e que, aliás, é manobrada politicamente por Sérgio Moro e Deltan Dallagnol. É claro que membros do aparato judicial não organizam a classe média, mas a interpelam desde o alto com mensagens genéricas e inclusive convocações de protestos de rua para pressionar o sistema político.

É correto afirmar que, além de representantes das classes médias, os membros do Judiciário e do MPF são representantes da burguesia associada ou mesmo do capital estrangeiro, por exemplo, por atacarem a Petrobras e os proprietários das construtoras mais próximas dos governos petistas, abrindo espaço para petroleiras e construtoras estrangeiras? Ou que fazem política em nome do PSDB, por causa do cálculo político na escolha de datas de operações e vazamentos para desestabilizar o governo Dilma e por pouparem, pelo menos de início, os tucanos?

É inegável que vários delegados, promotores e juízes passaram a fazer política por meios judiciais. Não obstante isso e a despeito do que ocorreu antes da aprovação do

${ }^{24}$ Nas palavras de Décio Saes (1985b, p. 286), usa-se “a expressão 'classe média', quando querem se referir a homens que exercem um trabalho remunerado (por salários ou honorários), predominantemente não-manual (concepção, direção, deliberação ou 'responsabilidade')... os trabalhadores dotados dessas características estão unidos, quaisquer que sejam as suas ocupações (médicos, advogados, jornalistas, bancários, etc.), por uma disposição ideológica comum... tendem, antes de mais nada, a defender a valorização socioeconômica do trabalhador (predominantemente) não-manual, baseando-se na concepção de que qualquer hierarquização dos trabalhadores (superioridade socioeconômica dos não-manuais sobre os manuais) se baseia fundamentalmente nas diferenças de capacidade individual (dons e méritos, conforme a expressão de Bourdieu e Pesaran)". Seguindo a importância conferida por Décio Saes (1975, $1977,1985 \mathrm{a})$ à estratificação social e às conjunturas e ideologias políticas na caracterização da diversidade da prática política das camadas médias, Cavalcante (2012) e Galvão (2016b) avaliam as posturas diferenciadas dos subgrupos da classe média na conjuntura atual. Para outras pesquisas sobre o tema pelo grupo vinculado ao Cemarx-Unicamp, ver Boito (1992, 2007), Trópia (2004) e Cavalcante (2012). Para a estratificação socioeconômica no Brasil, ver os trabalhos citados na nota de rodapé 12 . 
impeachment pela Câmara dos Deputados, as investigações da Lava-Jato não pararam depois do golpe e, como se sabe, ameaçam derrubar o governo Temer e os partidos de sua base de sustentação. Ao contrário do que esperavam vários intelectuais de esquerda (como SOUZA, 2016), o combate à corrupção não foi um mero pretexto para atacar um partido identificado com camadas populares. Devemos a um intelectual inglês radicado em Los Angeles, que observa à distância as paixões políticas brasileiras, Perry Anderson (2016), não apenas a primeira síntese histórica do golpe de 2016, mas também a hipótese de que as investigações se concentraram taticamente no PT porque era o partido que liderava o governo até 2016, sugerindo que precisavam dividir o sistema partidário para poder avançar e que não parariam com o golpe $\mathrm{e}^{25}$.

Para muitos membros do judiciário e do MPF, a luta contra a corrupção não é apenas um recurso hipócrita na luta de classes, mas um valor universal de que são portadores, pelo qual lutam e que, inclusive, justifica remuneração mensal que exorbita muito o teto do funcionalismo público. Enquanto os "marajás” do judiciário consideram não apenas legal, mas legítima e justa, a remuneração que recebem, as camadas populares tendem a se escandalizar não só com a corrupção, mas também com rendimentos mensais acima de 70 mil reais, como os que auferem Moro e Dallagnol. Os xerifes do judiciário sabem da desconfiança popular quanto a seus privilégios e, como portadores do meritocratismo e do republicanismo jurídico formal, interpelam a população com discursos a respeito da importância de sua defesa de valores éticos e com a lembrança da soma de recursos financeiros que suas operações contra a corrupção recuperam para o erário público.

${ }^{25}$ A mesma hipótese de cálculo tático do judiciário foi levantada por Armando Boito (2016a), que lembra que FHC precisou do beneplácito da mídia tradicional e de um procurador geral que era um "engavetador geral" para abafar o furor investigativo do Ministério Público, algo que Temer não conseguiu até agora. Nas palavras de Perry Anderson (2016): "Pode-se dizer que o judiciário brasileiro, assim como seus colegas de promotoria e Polícia Federal, compartilha muito da identidade de classe média brasileira, cujas camadas eles pertencem, com suas preferências e preconceitos de classe típicos. Nenhum partido operário, por mais emoliente que seja, consegue atrair simpatia particular desse meio. Mas será que os vazamentos contra o PT são resultado de uma aversão militante, ou fruto de uma ideia de que não há melhor forma de enfatizar os horrores da corrupção do que pegar aquela que é a principal força política do país por mais de uma década, que inclusive é justamente aquela que a mídia, por suas próprias razões, estaria mais disposta a divulgar as revelações? Histórias que atingissem o PMDB seriam banais e o PSDB poderia ser poupado, em âmbito nacional, pois sendo um partido de oposição teria menor acesso aos cofres públicos, independente do seu domínio dentro dos estados". Em um livro sugestivo, Jessé Souza (2016) chega a afirmar que a elite do direito ocupa o topo da hierarquia do mérito e da moralidade, que é recurso de distinção social típico do capitalismo, mas maximizado pelo "racismo de classe" herdado da escravidão no Brasil. Não obstante isso, Souza parece exagerar o papel instrumental do combate à corrupção para caçar o PT, sem sequer mencionar os possíveis desvios associados à diretoria da Petrobras ocupada por Renato Duque para financiar campanhas eleitorais do partido e mesmo a possibilidade de Caixa 3, cuja crítica e repressão são legítimas, evidentemente que não apenas por causa do dano político ao projeto partidário. 
É por isso que, ao invés de hipócritas que manipulam o combate à corrupção para fazer política partidária por meios judiciais, pode-se entender a cruzada do judiciário contra a corrupção como uma espécie de expressão tardia do "liberalismo doutrinário" conceituado por Wanderley Guilherme dos Santos (1978): a utopia originária da República Velha de criar regras legais e instituições que purifiquem a competição eleitoral, a utilização de recursos públicos e o acesso aos cargos públicos, de modo a barrar o uso do poder arbitrário e do dinheiro privado para financiar campanhas eleitorais, comprar votos ou contratos públicos, modificar leis e desviar mais dinheiro público. É claro que, como sempre, o apego a uma ética de princípios doutrinários pode ser contraproducente, ao não avaliar as consequências práticas de seu exercício em circunstâncias históricas particulares ${ }^{26}$.

Portadores maiores do meritocratismo que caracteriza as camadas médias, os membros do judiciário parecem realmente se achar melhores do que todos, de cima ou de baixo. Não são apenas instrumentos da classe dominante, mas têm ideologias e interesses próprios que podem se chocar com os da plutocracia e da oligarquia política; nem são apenas membros das classes médias, pois muitas vezes a conduzem pelo alto. Não se trata só de fiscalizar a política: sua luta contra a corrupção é encarada como uma luta para a refundação do Estado, eliminando os aspectos "patrimoniais" que consideram ser um atavismo brasileiro e não uma característica estrutural da imbricação entre poder econômico e político que é típica do capitalismo, apesar da distinção formal entre estas esferas e de sua autonomia relativa também típicas ${ }^{27}$.

${ }^{26}$ É por isso que o "liberalismo doutrinário" recebia a crítica dos "autoritários instrumentais" como Oliveira Vianna, que partilhavam algumas das finalidades, mas não dos métodos dos doutrinários.

${ }^{27}$ Sobre a imbricação real, a separação formal e a autonomia relativa entre o político e o econômico no capitalismo, ver Nicos Poulantzas $(1968,1978)$. Nos dois discursos de guerra contra o "patrimonialismo", Rodrigo Janot foi explícito quanto à intenção de refundar a República e eliminar seus supostos vícios de origem. Em 2014: "Avançamos, sem dúvida. Mas a tarefa ainda é imensa: nosso país padece de vícios graves em seu processo de desenvolvimento. O patrimonialismo e o fisiologismo de nossa formação social de origem ainda campeiam... Os anos de regime de exceção, nas duas metades do século XX, retardaram o desenvolvimento de uma cultura de transparência e de serviço público no Estado brasileiro. Em vez disso, a opacidade, o fetiche do sigilo e a cultura da autoridade deram o tom e o traço das relações dos agentes públicos com a sociedade civil por muito tempo, talvez por tempo demais, neste país... O Ministério Público Federal é órgão de Estado. Tem compromisso somente com a lei e com a sociedade, sendo constitucionalmente incumbido de preservar e defender o patrimônio público e a probidade administrativa" (OESP, 2014). Em 27 de junho de 2016, associou a Lava-Jato ao movimento pela abolição da escravatura: "A Lava Jato desvelou, como nunca, o sistema de favores mútuos entre políticos, partidos e empresários, que mais do que locupletar os seus sócios, frauda a democracia representativa, conspurca os valores republicanos e transforma o Estado em um clube exclusivo para desfrute de poucos, mas penosamente custeado por todos os brasileiros... A manutenção do escravismo entre nós foi justificada como tributo à estabilidade política, econômica e social... Há 130 anos rompemos os grilhões das senzalas...Chegou a hora, senhores e senhoras, de quebrarmos também os grilhões do patrimonialismo, de nos libertarmos de um modo de ser que não nos pertence, daquele malfadado jeitinho associado à corrupção da lei que não traduz nossa verdadeira natureza... O Brasil quer a República hoje, aqui, agora. Sem mais tardar" (AGUIAR, 2016). 
Nesse sentido, sua luta tem algumas semelhanças formais com a liderança de militares, advogados e engenheiros para despatrimonializar a ordem social e política e instituir o reino da concorrência entre homens livres (desiguais no mérito) e um Estado burguês (marcado pelo burocratismo) através do movimento abolicionista e republicano no final do Império, ou mesmo por meio do ataque à República "carcomida" para torná-la verdadeiramente "nacional" nos anos 1920, como estudado nos trabalhos clássicos de Décio Saes sobre a ação política das camadas médias movidas pelo meritocratismo ${ }^{28}$.

Uma diferença fundamental é que, hoje, conduzem a revolta da classe média desde cima e desde dentro do Estado, para fazer corresponder o Estado "real" à ordem legal já constituída e que lhes confere poder (inclusive para desrespeitar leis processuais ou o teto salarial do funcionalismo público). O projeto parece ser o de "purificar" radicalmente o Estado e a sociedade "realmente existentes" mesmo que se recorra a prisões arbitrárias e vazamentos seletivos de informações confidenciais ou meras denúncias, e mesmo que isso tenha consequências não inteiramente deliberadas como deslegitimar o sistema político e a própria atividade política (perante o autoritarismo purificador ou o mercado), ameaçar a democracia e o respeito à própria ordem legal (inclusive garantias individuais), eliminar organizações partidárias socialmente enraizadas, aprofundar a crise econômica, reforçar grupos políticos interessados em abafar as investigações e eliminar direitos sociais constitucionais (em nome do mercado e do ajuste fiscal), desmantelar os maiores grupos empresariais nacionais e desnacionalizar a economia ${ }^{29}$.

É verdade que a hipervalorização do burocratismo e do mérito (descontextualizado de condições sociais e explicado por atributos pessoais) tende a induzir preconceitos políticos particularmente com os de baixo, ou seja, contra os representantes de trabalhadores manuais menos qualificados no sistema escolar. Os meritocratas defendem o republicanismo e o mérito contra os sem mérito e/ou ética, tanto os debaixo quanto os de cima, mas a defesa da lei e da ordem, na tradição brasileira, tende a criminalizar movimentos sociais, criticar seu reconhecimento político como "populismo" e legitimar sua repressão arbitrária. Ademais, todos os partidos em todas as sociedades capitalistas indicam funcionários não concursados para cargos públicos, mas a antipatia contra o "apadrinhamento" é maior contra partidos de esquerda que, a despeito da competência organizacional e dedicação republicana, têm parcela significativa de

${ }^{28}$ Décio Saes (1985a, 1985b), a partir de teses defendidas em 1974 e 1983, assim como alguns artigos de síntese, por exemplo, Saes $(1977,1981,1992)$.

29 É digno de nota que, em artigo de 2004, Sérgio Moro argumenta que a Operação Mãos Limpas precisou deslegitimar o sistema político para avançar, o que trouxe o resultado indesejado de ascensão política de Berlusconi.Para uma crítica devastadora do artigo de Moro, ver Carta (2016). 
militantes cujas credenciais escolares dificultariam a ascensão ao aparelho de Estado por meio de concurso público.

Sendo assim, a cruzada do judiciário contra a corrupção não pode ser reduzida à mera prática da política partidária por meios judiciais, embora as predisposições ideológicas daqueles que a conduzem impliquem alguma seletividade contra os de baixo. É claro que, se a Operação Lava-Jato vier a parar voluntariamente antes da investigação do $\mathrm{PSDB}$, a interpretação feita aqui deverá ser revista: tratar-se-ia apenas de eliminar o PT e PMDB para deixar o caminho livre para o "ético" PSDB, talvez até mesmo reforçado pela filiação de algum juiz ou procurador missionário. Se é que estes não prefiram fundar um novo Partido da Reconstrução Nacional, desta vez conduzido pelos próprios marajás.

Seja como for, para entender a revolta social contra a corrupção e a política profissional é preciso entender que, para além das camadas médias, as camadas populares que são tocadas e mobilizadas pelo discurso contra a corrupção não são apenas uma massa de manobra de interesses que lhes são alheios. A ojeriza popular à corrupção não é irracional, pois a corrupção tende a aumentar a desigualdade e a injustiça de acesso aos recursos públicos que o capitalismo já produz por mecanismos legais. Aliás, parte da luta política de esquerda pela democratização de direitos políticos envolveu justamente transformar em ilegal o uso do dinheiro como método desigual de ação política. A luta pela universalização de direitos políticos envolveu não apenas eliminar as exigências de renda mínima para o direito de votar, mas também barrar a compra de votos e cargos públicos, o financiamento empresarial de campanhas políticas e mesmo o lobby para influenciar decisões parlamentares ${ }^{30}$.

Nessa luta pela democratização dos direitos políticos, é digno de nota que o judiciário superou limitações que o "presidencialismo de coalizão" e o sistema eleitoral brasileiro inviabilizavam reformar, como a pressão contra um sistema de votação manual sujeito a fraudes, a favor da lei da Ficha Limpa (de iniciativa do juiz Marlon Reis) e, principalmente, pelo veto a contribuições de empresas às campanhas eleitorais. Ademais, o MPF deu grande publicidade ao cartel montado pelas construtoras para manipular as licitações públicas, realçando o papel dos corruptores privados que a mídia tradicional prefere subestimar. A recusa a acordos de leniência, por outro lado, confundiu o destino dos executivos corruptores com os das próprias companhias, se-

${ }^{30}$ É por isso que, como insiste Jessé de Souza (2015), é completamente despropositada a crítica do "patrimonialismo" brasileiro e a idealização da democracia americana pelos intelectuais conservadores "colonizados até o osso", como Roberto Da Matta e Bolívar Lamounier, dada a legalização do financiamento empresarial de campanhas eleitorais (os chamados SuperPacs) e a compra de votos parlamentares por meio do lobby nos EUA. Sobre a história do "patrimonialismo" na democracia americana, ver Benson (1978), Grossman (2008) e Teachout (2014). 
guindo o padrão de desconsideração das consequências do embate doutrinário contra a corrupção ${ }^{31}$.

É evidente que, como afirmado, o ataque judicial às práticas escusas do presidencialismo de coalizão foi e é manipulado pelo discurso neoliberal para tornar-se uma rejeição à política como um todo. Depois de jogar o bebê junto com a água suja, a intenção é valorizar o mercado, ou melhor, as relações mercantis assimétricas que são dominadas, legalmente, por muitos dos empresariais que são corruptores no trato com a política. Estes, aliás, prefeririam se possível eliminar os intermediários políticos e comprar o patrimônio público em nova rodada de privatização, que só pode ser legitimada, mesmo em cenário de crise econômica, pela deslegitimação da política com a generalização de escândalos de corrupção. Para evitar isso, a esquerda precisa reconceituar e liderar a luta contra a corrupção, oferecendo como alternativa a democratização do Estado e da esfera pública, ao invés da privatização do patrimônio público e o monopólio do espaço público pelas empresas controladoras dos meios de comunicação.

Não fazer isso é fatal para as outras pautas estratégicas de esquerda e para as próprias organizações de esquerda. Como os partidos de esquerda se fundamentam em valores críticos da desigualdade e da injustiça, e na valorização das instituições estatais e dos direitos políticos democráticos para reverter assimetrias de poder econômico, seu envolvimento em casos de corrupção é fatal para sua reputação e ação junto às camadas populares. Não conseguem se eleger, como Adhemar de Barros ou Paulo Maluf, com o lema "rouba, mas faz". É por isso que a condescendência com a corrupção pode diminuir, em curto prazo, as desvantagens financeiras de partidos de esquerda na concorrência eleitoral com partidos de centro e direita preferidos pelo financiamento empresarial, mas tende a ameaçar sua própria sobrevivência em longo prazo, ou pelo menos inviabilizar suas demais pautas estratégicas.

${ }^{31}$ Sobre o significado dos arranjos tradicionais do "presidencialismo de coalizão" e o controle da agenda parlamentar pelas grandes empresas privadas que cartelizam licitações para obras públicas, a delação do diretor da Odebrecht, Claudio Melo Filho, apresentada em 9 de dezembro de 2016, é cristalina: "Sabia que o apoio legislativo oferecido pelos agentes políticos às empresas se dava, na prática, ao menos em troca de contribuições em períodos eleitorais, quando não em troca de contrapartidas financeiras mais imediatas... Por causa disso, vários agentes políticos tentaram se aproximar de mim. Valendo-me da situação, percebi que deveria selecionar determinados agentes com relevância política e que teriam melhores condições de gerar resultados positivos para a minha empresa... que preferencialmente exercem forte liderança em seu partido e em seus pares. A minha empresa tem interesse na permanência desses parlamentares no Congresso e na preservação da relação, uma vez que historicamente apoiam projetos de nosso interesse e possuem capacidade de influenciar os demais agentes políticos. O propósito da empresa, assim, era manter uma relação frequente de concessões financeiras e pedidos de apoio com esses políticos, em típica situação de privatização indevida de agentes políticos em favor de interesses empresariais nem sempre republicano" (MPF, 2016, p. 5). 
Para assegurar sua sobrevivência em longo prazo, os partidos de esquerda precisam enfrentar não apenas os males específicos do "presidencialismo de coalizão", mas algo bem mais profundo: a tendência inerente à concorrência capitalista de disputas por contratos (públicos e privados) e busca de rendas extraordinárias por meio da corrupção, o que envolve a cooptação tanto de funcionários de outras empresas quanto de elites políticas com favores monetários. Os partidos devem coibir, em particular, a tendência à imitação dos modos de vida das elites econômicas por elites políticas que não resistem ao "discreto charme da burguesia", mas não têm renda suficiente para gozá-lo ${ }^{32}$.

Políticos privatistas e entreguistas podem ser favorecidos pelo ataque contra a corrupção, mas é difícil saber o quanto isso é um objetivo deliberado ou um dano colateral da Operação Lava-Jato. Um empresário aventureiro como Berlusconi foi o principal favorecido pela operação Manu Puliti na Itália, e o discurso de campanha de outro empresário aventureiro à prefeitura de São Paulo, João Dória, fazia referência ao fato de ser um empresário rico que não precisava de um cargo público para enriquecer, ao contrário dos demais políticos profissionais ${ }^{33}$.

Não é possível dizer, contudo, que privatizar e desnacionalizar o patrimônio público seja o objetivo central da Operação Lava-Jato, muito embora a idealização do "destino manifesto" dos Estados Unidos para democratizar e modernizar o mundo seja evidente no discurso do integrante menos ilustrado da Operação Lava-Jato, o procurador Deltan Dallagnol. Isso o aproxima dos economistas neoliberais do governo Temer. No entanto, a própria Operação Lava-Jato ameaça implodir esse governo e sua base partidária, enquanto o TCU proibiu a Petrobras de vender ativos por irregularidades nos processos adotados para fazer os chamados "desinvestimentos" (FABRINI, 2016).

Seja como for, as camadas médias tradicionais são a base de massas que votou na oposição à frente neodesenvolvimentista de 2006 a 2014, que se projeta nos xerifes

32 Em um livro de alerta para a esquerda, Jacob Gorender (1999, p. 46) fez uma avaliação fulminante desta tendência: "Mais uma circunstância importantíssima influi no comportamento dos políticos profissionais, assegurando sua fidelidade aos interesses gerais da burguesia... Tal circunstância consiste no fato de que só por exceção o político profissional é um asceta, motivado unicamente pelos princípios cívicos. Comumente, ambiciona ser burguês ao mesmo título que seus patrocinadores, dispondo de patrimônio e de padrão de vida equivalentes aos deles. Afinal, por que deveria o deputado ou ministro se contentar com os vencimentos protocolares, enquanto os empresários, cujas causas eles defendem, se fartam de riquezas crescentes?... no Brasil como nos países considerados sérios, não faltam os mil e um jeitinhos, incluindo a passagem pelos campos minados da corrupção, que conduzem o político profissional de origem modesta à fortuna pessoal. Vez por outra, explodem os escândalos... Porém a repetição indefinida desses escândalos demonstra que se trata de procedimento sistemático, inextirpável da vida pública burguesa”.

${ }^{33}$ Outro potencial beneficiário da aversão à política profissional trazida pelos escândalos de corrupção, Jair Bolsonaro, tem um discurso muito menos liberal do que João Dória (KLEIN, 2016). 
da Lava-Jato e que compareceu, junto a outros grupos minoritários, aos protestos de junho de 2013 e em 2015-2016 $6^{34}$.

O primeiro governo Dilma continuou erodindo a renda real e o status social dessas camadas ao apoiar legislação que, em 2011, garantiu aumentos reais do salário mínimo até 2015 e, em 2013, estendeu direitos trabalhistas aos empregados domésticos, exatamente no ano em que a média classe média e a alta classe média encolhiam no Brasil e, principalmente, em São Paulo. A inexistência desses direitos e seus baixos salários eram, como se sabe, uma tradição brasileira arcaica, herdada da escravidão e muito prezada por burguesias e camadas médias ${ }^{35}$.

Assim, desenhava-se no final de 2013 um cenário em que parcelas crescentes do empresariado e das camadas médias se rebelavam contra o ganho de poder econômico e político dos trabalhadores organizados e dos trabalhadores menos qualificados, e contra as políticas distributivas executadas pelos governos petistas para atender à sua base social, sistematicamente majoritária nas eleições presidenciais.

Essa revolta parece ter contado com o esforço de financiamento legal e ilegal de campanhas de deputados contrários ao PT nas eleições de 2014, tendo provavelmente envolvido várias lideranças parlamentares, sendo Eduardo Cunha a principal ligação entre os financiadores empresariais e o PSDB, o PMDB e partidos conservadores menores. Nessa revolta, as acusações de corrupção investigadas pelo MPF, PF e Sérgio Moro davam mais legitimidade à reação antissocial de empresários e camadas médias conservadoras contra a ascensão social dos de baixo. É por isso que alguns representantes dessa revolta alegavam que o sistema político brasileiro estava montado para que eles perdessem sempre as eleições, à medida que o governo "comprava" campanhas eleitorais caras e engenhosas, mas também o apoio de massas que sequer se sensibilizavam com

34 As pesquisas sobre o perfil dos manifestantes em 2015 em São Paulo indicam que 70\% tinham ensino superior completo e de $40 \%$ a $50 \%$ possuíam renda mensal superior a 10 salários mínimos: Datafolha (2015a, 2015b), FPA (2015), Ortellado et al. (2015a, 2015b) e Pochmann (2015).

35 Sobre a história do trabalho doméstico e suas transformações recentes no Brasil, ver Melo (1998), Kofes (2001) e Furno (2016). A herança da escravidão é evidente na seguinte entrevista nos anos 1960 do clássico A integração do negro na sociedade de classes de Florestan Fernandes: "Outra evidência notória de status consiste 'em ter posses para contratar empregada'. A 'mulher de cor', no passado e ainda hoje, sempre forneceu forte contingente das domésticas da capital... A expectativa de que a 'preta' seja sempre 'empregada doméstica' faz com que a 'mulher de cor' de classe média se defronte com certos 'aborrecimentos' frequentes. Eis como o marido descreve os dissabores da esposa, daí resultantes: 'Ela sofre muito com os desaforos de gente que vai bater na porta, para oferecer verduras, artigos domésticos etc. Quando ela sai na janela ou chega à porta, logo recebe uma pergunta como esta: 'A patroa está? Eu quero falar com ela!' 'Vá chamar sua patroa, que tenho um assunto para tratar com ela.' Alguns são ainda mais atrevidos e malcriados. Quando ela diz: 'A patroa sou eu', eles respondem: 'Deixe de brincadeira. Eu não tenho tempo a perder. Vá chamar sua patroa!’. Eles pensam que o preto não pode ter uma casinha melhor e viver com mais decência" (FERNANDES, 1962, v. 2, p. 233-234). 
as denúncias de corrupção ao receberem benesses governamentais, com grande preconceito contra nordestinos, "manos" da periferia, cotistas e beneficiários do Bolsa Família.

A despeito das resistências citadas, muitas delas envolvidas em ódio avesso a qualquer diálogo, Dilma Rousseff venceu a eleição de 2014 porque, apesar do baixo crescimento econômico, sua campanha televisiva e milhares de militantes voluntários foram capazes de mostrar, corretamente, o conteúdo classista do programa neoliberal e a vinculação dos economistas dos dois principais candidatos de oposição à visão "austérica" exigida pelos mercados financeiros. A reviravolta depois das eleições teve resultados bastante diferentes dos esperados pelo núcleo decisório do governo.

\section{O “AUSTERICÍDIO” E O GOLPE DE 2016}

O ano de 2015 não era 2003, mas o governo reeleito resolveu repetir a mágica da conciliação de opostos e do governo de "união nacional" do início do ciclo lulista. O problema é que, do ponto de vista econômico, essa "conciliação nacional” tinha por base o programa da oposição de direita que acabara de vê-lo derrotado nas urnas. Por que não tinha por base o programa nacional vitorioso?

O cálculo das viradas para a direita de governos de centro-esquerda é sempre o de que seus apoiadores à esquerda não têm para onde correrem no curto prazo, mas que a reviravolta é capaz de desarmar a escalada de hostilidade à direita até que, em médio prazo, o crescimento seja retomado. Um governo de esquerda reformista não pode governar o capitalismo contra uma unificação da burguesia, ou seja, sem dividi-la, e tende a cair caso a unificação ocorra e ele não esteja fortemente enraizado socialmente. Minha hipótese é que, politicamente, a intenção em 2015 era trazer a burguesia bancária para o governo e desarmar a possibilidade de unificação do conjunto da burguesia que, ao contrário, a recessão e o enfraquecimento político resultante acabaram produzindo, ao mesmo tempo em que solapavam as bases sociais do governo, deixando-o solto no $\mathrm{ar}^{36}$.

${ }^{36}$ Essa hipótese foi apresentada dois dias depois do segundo turno, em 28 de outubro de 2014, no artigo "O terceiro turno já começou, o austericídio também?", que alertava para o golpismo e para a inexistência de condições políticas e econômicas propícias para a austeridade: "Se ceder à coação política implícita no terrorismo de mercado, Dilma Rousseff arrisca ganhar credibilidade perante o mercado, mas arriscar sua credibilidade perante o eleitorado, exatamente quando mais precisar dela para lutar pela reforma política que diz ser sua prioridade legislativa. Ou quando seu governo for julgado politicamente pelos possíveis desvios da Petrobrás. Arrisca ganhar reputação perante o mercado, mas desmobilizar a energia e o apoio dos que a elegeram, exatamente quando for chamada a disputar o terceiro turno" (BASTOS, 2014b). Em artigo enviado para publicação e para a equipe do futuro Ministro do Planejamento em dezembro de 2014, argumentei que: "Uma recessão não é um evento classificado benignamente pelas agências de classificação de risco, por mais estranhos sejam seus critérios de avaliação. Embora deva resultar de políticas 
Assim como não houve recessão em 2014, tampouco houve unificação da burguesia nesse ano. Algum grande empresário financiaria a campanha de reeleição de Dilma - mais rica que a de Aécio - caso participasse de uma frente de oposição para derrubar o governo?

De todo modo, a intenção com a convocação para o Ministério da Fazenda do presidente do Bradesco, Luiz Carlos Trabuco, e a nomeação do diretor-superintendente do banco, Joaquim Levy, era trazer para dentro do governo representantes da burguesia bancária que foi hostilizada por Dilma em 2012, desarmando sua oposição. O preço era executar um ajuste fiscal que era apontado pelos economistas neoclássicos neoliberais, como o próprio Levy, como inevitável para reverter a "gastança" que alegavam estar no centro da perda de confiança com a dívida pública, entendida como o motivo da desaceleração do investimento privado e do próprio crescimento econômico.

$\mathrm{O}$ argumento neoliberal tem um quê de absurdo: é difícil imaginar como a economia não desaceleraria mais ainda caso o Banco Central elevasse ainda mais a taxa de juros básica, enquanto o Tesouro cortasse ainda mais o investimento público. De todo modo, é digno de nota que a dívida pública líquida estava em um patamar muito confortável em 2014 e não exigia uma política fiscal contracíclica. A despeito do deficit primário de 2014, a relação dívida líquida/PIB alcançou apenas 33,1\% do PIB, sendo inferior ao patamar de 2010 (38\%) e 2011 (34,5\%), ou mesmo de 2008 (37,6\%), quando se considerou necessário (e possível) realizar um programa anticíclico para reverter a recessão provocada pela crise financeira global no Brasil. É por isso que há dúvidas sobre se Dilma Rousseff foi convencida pelo argumento da oposição neoliberal ou se aderiu a ele apenas por causa dos efeitos políticos esperados ${ }^{37}$.

O pacote não se limitava ao ajuste fiscal e acelerava o ajuste de preços relativos, particularmente da relação câmbio/salários, iniciado em 2011. Agora, ele não se concentrava na desvalorização cambial e sim também na redução dos salários reais e do

exigidas pelos porta-vozes dos mercados financeiros, é duvidoso que seja capaz de comprar-lhes a boa vontade... Uma recessão tampouco deve facilitar a governabilidade diante de um Congresso Nacional que é muito demandante de verbas e cargos. Principalmente se a recessão empurrar as ruas contra um governo acuado por denúncias de corrupção e por uma oposição inconciliável e, até, constituída por alguns políticos que mal disfarçam o golpismo" (BASTOS, 2015a).

37 O relato de bastidores feito por seu ex-assessor de imprensa entre setembro de 2015 e abril de 2016, e de Levy entre abril e setembro de 2015, sugere que ela foi convencida (ALMEIDA, 2016). Em entrevista em agosto de 2015, a presidenta afirmou que a descoberta tardia da queda de arrecadação tributária no final de 2014 é que lhe mostrou o quanto a situação era grave, na mesma linha do argumento pré-keynesiano de Levy segundo o qual a resposta a uma desaceleração do gasto privado (que produz a queda da arrecadação) deve ser o corte simultâneo do gasto público (NERY, 2015). É digno de nota que, em 2014, as disponibilidades do Tesouro Nacional depositados na Conta Única no BCB atingiam nada menos que 10,7\% do PIB e 32\% do total da dívida líquida, não sendo contabilizada em seu cálculo porque são ativos do Tesouro, mas passivos do BCB. Se fossem depositados em bancos privados como em outros países, reduziriam a dívida líquida para $22,5 \%$ do $\mathrm{PIB}$ ! 
nível de emprego, exatamente o ponto que poderia unificar a burguesia, mas afastar o eleitorado e a base social do governo. É claro que tal objetivo não podia ser expresso claramente, mas o argumento técnico é que o desemprego estava abaixo da taxa "natural" de desemprego: a pressão de demanda excessiva por trabalhadores, em relação à oferta, aumentava salários sem aumentar mais o emprego, aumentando custos, gerando inflação e reduzindo poupanças disponíveis para o investimento empresarial. Joaquim Levy afirmou em junho de 2015 que havia gente que não queria entrar mais no mercado de trabalho, mas voltaria, com a recessão, a procurar emprego, o que seria bom, pois "não existe crescimento sem aumento da oferta de trabalho" 38 .

A austeridade fiscal e salarial seria ainda complementada pelo ajuste abrupto de preços relativos, ao contrário da proposta de ajuste gradual feita em campanha eleitoral: a desvalorização do Real perante o dólar deveria acelerar para aumentar exportações e reduzir importações; e os preços administrados pelo governo, como energia elétrica, petróleo e derivados, serem elevados para reduzir subsídios ao setor elétrico e melhorar contas da Petrobras.

O timing do ajuste foi péssimo do ponto de vista econômico e político: um "austericídio". Economicamente, subestimou a desaceleração cíclica e o efeito contraproducente da austeridade. Politicamente, como a presidenta admitiria mais tarde, o núcleo decisório subestimou o golpismo da oposição, expresso já no discurso de aceitação da derrota por Aécio Neves ${ }^{39}$.

Subestimou também a seletividade da Operação Lava-Jato e a credulidade e boa vontade da população, que havia dado um voto de confiança ao governo que prometera, contra seus adversários, preservar o nível de emprego e salários. Diante da acusação previsível de estelionato eleitoral feita pela oposição e reverberada pela mídia, sua popularidade despencou antes mesmo da posse e não mais se recuperou, sendo impossível apelar às ruas, em massa, para barrar o golpe. O impeachment, ao contrário, é que se popularizou, à medida que a crise econômica e a Operação Lava-Jato

38 Ver Bastos e Belluzzo (2016) para a crítica teórica desse argumento, que foi expresso com clareza por Pinotti e Pastore (2014). Levy é um engenheiro naval que concluiu doutorado em economia na Universidade de Chicago em1992, no auge do triunfalismo neoliberal pós-Guerra Fria, e talvez não tenha conhecido as críticas que já tornavam o conceito taxa "natural” de desemprego de Milton Friedman muito questionável em 1992, e praticamente descartado internacionalmente (exceto entre os mais radicais neoliberais de Chicago) em 2014. Para uma apresentação teórica simples do problema, ver Quiggin (2011) e Bastos (2017); para uma crítica à hipótese de pleno emprego no Brasil em 2014, ver Mattos e Lima (2015). O artigo conjunto não se concretizou. Escrevi sozinho, sendo Bastos (2017).

39 Para a mea culpa de Dilma, ver a entrevista de Dilma Rousseff à revista Carta Capital (BARROCAL et al., 2016) em 22 de maio de 2016: "As pessoas tentam e às vezes erram. Nós pensamos que seria possível um processo de ajuste de um ano, mas era incompatível em 2015 com a realidade política do país”. 
destruíam a confiança no governo, sem que um bom desempenho econômico pudesse compensar o ataque judicial e político golpista ${ }^{40}$.

$\mathrm{O}$ ajuste fiscal pró-cíclico também pode ter, inicialmente, satisfeito às demandas dos empresários que não entendiam que a queda do gasto público significa redução de suas próprias receitas privadas. A redução do crédito livre em 2014 indica que consumidores estavam prestes a "desalavancar", e a queda de receitas das empresas em 2015 não levou as empresas a reagirem ao corte de gasto público aumentando seus próprios gastos, mas se retraindo diante de um futuro incerto e poupando para pagar dívidas. A tentativa de "desalavancagem" de empresas, porém, reduz seus gastos e, no agregado, suas receitas, assim como a arrecadação tributária, frustrando o próprio esforço fiscal de Joaquim Levy.

A cada revisão bimestral da política fiscal em meio à queda de arrecadação, Levy insistia em seu esforço de ganhar a confiança empresarial e do mercado financeiro cortando ainda mais o gasto público. Mesmo depois de conhecido o deficit fiscal de $0,63 \%$ do PIB em 2014, ele continuou se comprometendo com a meta fiscal de $1,2 \%$ do PIB, o que levaria o esforço fiscal em 2015 para 1,83\% do PIB: um irrealismo completo em uma economia em recessão, vindo de quem dizia que um dos problemas da gestão fiscal anterior era a falta de realismo e transparência. O compromisso com a meta irrealista implicava responder à queda do gasto privado e da arrecadação tributária pró-ciclicamente, ou seja, com novos cortes concentrados em investimento público, ou gastos discricionários em saúde e educação.

Como esses gastos têm um grande multiplicador fiscal, isto é, o montante que a renda nacional cresce (ou cai) para cada Real gasto (ou eliminado) pelo governo, seu corte reforçava a queda das receitas privadas, levando-as a novos cortes que, por sua vez, também impactavam a arrecadação tributária. Assim, o ajuste fiscal era contraproducente para sua finalidade declarada, melhorar o resultado fiscal ou, pior ainda, a relação dívida pública/PIB. O esforço tributário da União chegou a, pelo menos, $0,44 \%$ do PIB, com ganho de carga tributária de apenas $0,12 \%$. Como dizia Keynes, se há algum momento propício para a austeridade, esse é o boom e não a recessão. É melhor aumentar a relação dívida/PIB ao gastar para evitar uma recessão do que por causa da recessão.

O momento certamente não era propício à austeridade, porque ela reforçou uma desaceleração cíclica já em curso e aumentou muito a incerteza de empresas, traba-

${ }^{40}$ Em seu discurso de defesa no Senado em 28 de agosto de 2016, Dilma conferiu importância crucial à crise econômica para explicar o golpe: "Muitos (congressistas) articularam e votaram contra propostas que durante toda a vida defenderam, sem pensar nas consequências que seus gestos trariam para o país e para o povo brasileiro. Queriam aproveitar a crise econômica, porque sabiam que assim que o meu governo viesse a superá-la, sua aspiração de acesso ao poder haveria de ficar sepultada por mais um longo período." 
lhadores e consumidores. A queda do preço das commodities, a operação Lava-Jato e a possibilidade de racionamento de água e energia também contribuíam para jogar a economia na recessão, assim como as demais políticas de ajuste:

i) elevação brusca de alíquotas de impostos e preços administrados;

ii) impacto da elevação de taxas de câmbio e juros no custo da dívida interna e externa das firmas;

iii) opção pela redução do emprego e do salário real, o que deprime o consumo das famílias e a receita das empresas, antes que seus custos.

A piora dos balanços empresariais não levou os empresários a rejeitar o remédio que os matava, pois o clamor por ajuste fiscal não diminuiu logo. Ainda em novembro, Levy foi capaz de recorrer ao apoio de grandes empresários (e não apenas banqueiros) para pressionar o governo a evitar uma meta fiscal mais realista para 2016. Logo depois de vencer a última batalha contra Nelson Barbosa e armar mais uma bomba de efeito retardado (a meta primária de $+0,7 \%$ para 2016), Levy sinalizou sua demissão como se estivesse demitindo o próprio governo no qual sua vontade, que expressava a visão dos mercados financeiros, não era sempre soberana, como no debate sobre o limite legal para a dívida pública em novembro de $2015^{41}$.

No contexto e na forma como foi feito, o ajuste fiscal teve efeito oposto ao esperado também no que tange ao apoio empresarial. Os que acreditavam na sua viabilidade em uma recessão se frustravam com o deficit e exigiam ainda mais cortes. Os que pediam cortes talvez não soubessem que eles contribuíam para a queda de sua própria renda, e seu descontentamento com o governo também aumentava à medida que a renda caía. Assim, o segundo governo Dilma Rousseff incorreu no custo político de executar a agenda empresarial e conservadora sem, com isso, porém, recriar o amplo apoio empresarial gozado no início do primeiro mandato. Ao contrário, o resultado da virada de política econômica foi aprofundar a perda de lucratividade e o descontentamento empresarial, e também detonar uma grande perda de popularidade inclusive em sua base de apoio tradicional.

Realizar uma contração fiscal em meio a uma recessão sempre traz custos políticos mesmo para um governo com ampla governabilidade junto ao poder legislativo e grande popularidade. O custo político incorrido pelo governo aumentou porque, primeiro, o Congresso Nacional eleito em 2014 era o mais conservador da redemocra-

${ }^{41}$ Para o recurso de Levy a grandes empresários e banqueiros para impor ao governo o aprofundamento do austericídio em 2015, ver Almeida (2016, cap. 9). Para sua defesa do limite da dívida pública no Senado Federal contra a orientação do governo, ver Senado (2015, p. 3). 
tização. Segundo, porque a tentativa inicial de enfraquecer o peso do PMDB na base parlamentar do governo teve como saldo, ao contrário, o seu fortalecimento e a eleição de Eduardo Cunha à presidência da Câmara. Terceiro, porque a operação LavaJato minou os arranjos políticos invisíveis que contribuíam para a governabilidade do “presidencialismo de coalizão" brasileiro, enquanto os mecanismos mais tradicionais de governabilidade (distribuição de verbas, obras e cargos públicos) foram fortemente prejudicados pela contração fiscal, inclusive pelo veto frequente de Joaquim Levy à liberação de emendas parlamentares ${ }^{42}$.

É difícil saber se o ajuste fiscal foi mais importante que a Operação Lava-Jato para enfraquecer governo, mesmo porque suas operações e vazamentos eram calculadas para reforçar sua oposição política e social. No plano econômico, a resistência da LavaJato a acordos de leniência contribuiu com a queda do preço do petróleo para a crise na cadeia de petróleo e gás, associada à decisão intempestiva da direção da Petrobras de interromper encomendas de empresas denunciadas.

A Lava-Jato também neutralizou, pelo medo ou pela prisão, a camada empresarial mais próxima do governo. Paradoxalmente, o fato de o governo Dilma Rousseff apoiar a Lava-Jato o enfraqueceu em outro sentido. Políticos e empresários envolvidos em transações ilegais tinham interesse evidente em substituir o governo por outro capaz de barrar ou limitar as apurações e patrocinar algum tipo de anistia dos crimes cometidos, como ficou evidente nas conversas com Romero Jucá e José Sarney gravadas por Sérgio Machado ${ }^{43}$.

Não foi a Operação Lava-Jato, contudo, que mudou a agenda estratégica do país. O recuo tático representado pelo ajuste recessivo acabou sendo mais do que isso: a perda da iniciativa estratégica. Ao eleger-se com um programa e dizer que ele deve ser adiado porque é inviável, como voltar atrás de novo? Sem voltar atrás na virada, com qual programa o governo vai convocar as ruas para defendê-lo? A virada de 2015 simplesmente deixava o governo sem alternativa estratégica e sem discurso econômico para apelar ao povo e recuperar a popularidade.

Assim, à medida que os ataques se ampliavam, os recuos se sucediam em um esforço desesperado do governo de sinalizar ainda mais para a centro-direita e para o empresariado, procurando apoios contra a ameaça de Eduardo Cunha de aceitar al-

42 Segundo o relato de Rodrigo de Almeida (2016, p. 58, 79, 139-40). Para o papel da Operação Lava-Jato para minar arranjos tradicionais do presidencialismo de coalizão brasileiro, ver Anderson (2016), Avritzer (2016) e Nobre (2016). Para uma crítica da categoria de "presidencialismo de coalizão", ver Martuscelli (2010).

${ }^{43}$ Nas palavras de Jucá, “Tem que resolver essa porra... Tem que mudar o governo pra poder estancar essa sangria... (eles querem) acabar com a classe política para ressurgir, construir uma nova casta, pura, que não tem a ver com..." (VALENTE, 2016). 
gum dos pedidos de impeachment. Mas cada concessão enfraquecia ainda mais o governo e levava a um novo recuo. Talvez a concessão mais criticada tenha sido o acordo para a mudança no regime de exploração do pré-sal, mas o apelo mais desesperado de união nacional, sem combinar a adesão dos russos, foi do ministro da Casa Civil, Jacques Wagner, sobre a reforma da previdência em janeiro de 2016:

A presidente não está preocupada em recuperar a popularidade, ela está preocupada com o bem do Brasil. Tanto é que está insistindo em fazer a reforma da Previdência, cujos efeitos imediatos não serão sentidos no governo dela. (BARRETO, 2016)

A opção do núcleo decisório do governo foi a de sacrificar a popularidade para alcançar a governabilidade. Mas sem popularidade, como manter a governabilidade perante um legislativo e um judiciário hostis?

Partir para a retranca no segundo governo não era a única opção, pois às vezes a mudança de rota não tem volta. Diante do ataque alheio, o contra-ataque e a marcação no campo do adversário podem ser mais eficazes para evitar a derrota e conseguir pelo menos um empate. Reforçar, mobilizar e ampliar suas bases sociais, ao invés de mandá-las para casa, desmobilizadas e amuadas, pode forçar um recuo alheio e gerar um equilíbrio (instável) em outro patamar, ao invés de convidar a oposição a escalar seus ataques e forçar novos recuos passivos.

O sociólogo André Singer (2015) explicou o fracasso do programa social e desenvolvimentista do primeiro governo Dilma pela inexistência de bases sociais, mas a população foi mobilizada para virar uma eleição perdida em 2014 quando as lideranças fizeram um discurso à esquerda. É verdade que, sem bases populares, lideranças de esquerda não se capacitam para negociar com os poderes constituídos, mas a inércia ou a mobilização das massas depende em grande parte da postura defensiva ou ofensiva das lideranças. De todo modo, continua sendo difícil comprovar a unificação da burguesia em 2014 (e não no final de 2015), pois, repito, a campanha de reeleição de Dilma não seria mais rica que a de Aécio caso os empresários estivessem participando de uma frente de oposição para derrubar o governo. A unificação empresarial contra o governo, de um lado, e a perda de popularidade, de outro, parece resultado de processos e eventos ocorridos depois de 26 de outubro de 2014.

Seja como for, não há caso histórico de criação de um Estado de bem-estar sem mobilização social e participação ativa das lideranças políticas e intelectuais na luta para forçar a aceitação, pelas classes dominantes, de um novo mundo de direitos sociais baseado em um novo equilíbrio (instável) de compromisso. Em qualquer lugar do mundo, as burguesias tendem a preferir manter as interações sociais reguladas apenas pelo mercado e pelas assimetrias monetárias, sendo menos convencidas do 
que forçadas a aceitar a cidadania ampliada, isto é, a intromissão de direitos sociais no capitalismo. Isso talvez seja ainda mais evidente no caso no Brasil, por causa das desigualdades profundas geradas pelo projeto escravocrata que orientou nossa formação social.

A propósito, em 1935, Getúlio Vargas solicitou que Assis Chateaubriand organizasse um almoço com a nata do empresariado brasileiro, de modo a promover uma frente ampla contra a ameaça comunista. O jantar se realizou na casa de Guilherme Guinle, diretor do Centro Industrial Brasileiro (CIB), embrião da FIRJAN. Ao invés de obter a adesão para uma cruzada contra o comunismo que contasse também com o envolvimento dos trabalhadores graças aos direitos trabalhistas - que considerava o antídoto contra o extremismo comunista, segundo o relato de Alzira Vargas -, Getúlio passou o almoço ouvindo reclamações contra o despropósito das leis trabalhistas e o rigor dos fiscais do Ministério do Trabalho. Já no carro, Getúlio desabafou ao ajudante-de-ordens que o acompanhava, o capitão-tenente Ernani do Amaral Peixoto: "Eu estou tentando salvar esses burgueses burros e eles não entenderam”. A Consolidação das Leis do Trabalho (CLT) ainda demoraria oito anos para ser sancionada ${ }^{44}$.

Perseguido pelo Estado Novo depois da repressão aos comunistas, Caio Prado Júnior passava o exílio na Suécia, em 1938, quando anotou em um manuscrito intitulado Cultura Nórdica e Cultura Moderna, que haveria em meio à classe dominante sueca um "reconhecimento da necessidade de um bem-estar geral" da população. Na verdade, a aceitação de leis trabalhistas e do Estado de bem-estar social na Suécia não foi nada tranquila. Em 1938, o acordo tripartite de Saltsjöbaden foi celebrado depois de duas décadas de militância política, embate ideológico e conflitos sociais. Nos EUA, por sua vez, o Segundo New Deal, que estendeu direitos trabalhistas e previdenciários a partir de 1935, só foi possível pela pressão do movimento "Share Our Wealth", liderado, à esquerda de Franklin Delano Roosevelt, pelo governador de Louisiana, Huey Long, e das pregações sociais radiofônicas do reverendo Charles Coughlin, em meio a uma onda de protestos, greves e vitórias eleitorais. O mesmo processo ocorreu no Japão, que perdeu mais dias de trabalho por conta de greves do que a Inglaterra ou a França entre 1955 e 1964, até que os trabalhadores conseguissem instituições "tipicamente"

${ }_{44}$ Morais (1994, p. 360). Depois do putsch comunista de novembro de 1935, a situação mudou um pouco. Assim que, em janeiro de 1936, o projeto de lei instituindo o salário mínimo foi apresentado, o jornal $O$ Estado de São Paulo declarou em editorial: "No dia em que, com a adoção do salário mínimo, a miséria do operariado houver desaparecido e a exploração dos humildes pelos poderosos se tornar impossível, o comunismo teria perdido o seu melhor argumento e o recurso mais seguro para a propaganda... Algo que teríamos que fazer mesmo que o comunismo não existisse; já que ele está aí, façamos imediatamente" (BRANDI, 1983, p. 101). Mas a repressão ao comunismo foi tão eficaz que a lei do salário mínimo só entrou em vigor em $1^{\circ}$ de maio de 1940. 
japonesas, como o emprego vitalício e benefícios sociais dentro da empresa, em troca da cooperação com a gerência para a promoção da produtividade ${ }^{45}$.

No caso brasileiro de 2015, a busca deliberada da governabilidade pela moderação do conflito em prejuízo da popularidade, e a virada em direção ao centro político e a uma política econômica de direita em prejuízo do nível de emprego, não tiveram volta. Os que pediam uma virada à esquerda ficaram esperando Godot. Ao invés de moderar a resistência da direita ao programa de domesticação gradual do capitalismo selvagem brasileiro, a virada e a crise tendiam a unificar o empresariado em torno da agenda de cortes fiscais (seletivos), salariais e de direitos, transferindo a contados subsídios, desonerações fiscais e da baixíssima carga tributária dos ricos para trabalhadores e beneficiários de serviços públicos, contra a CLT e o capítulo social da Constituição Federal.

A unificação da burguesia em torno de um programa regressivo finalmente aconteceria caso uma alternativa política viável ao governo aparecesse, o que ocorreu quando, de dentro dele, Michel Temer anunciou o programa Uma Ponte para o Futuro. É ele a inspiração da PEC 214/55 do teto do gasto, que poupa a estrutura tributária regressiva, distribui o ônus do ajuste para os cidadãos pobres carentes de transferências monetárias e serviços públicos (mas que pagam proporcionalmente mais impostos que os ricos) e abre um novo horizonte de privatizações do domínio público. Se o golpismo da oposição era previsível em 2014, o golpismo do Palácio do Jaburu era muito menos. A Ponte para o Futuro transformava o recuo tático em nova estratégia, o que, faça-se justiça, estava muito distante das intenções de Dilma Rousseff. Junto com a expulsão de Dilma, iriam a CLT e a Constituição "cidadã"46.

45 Para o caso sueco, ver Blyth (2002, p, 114-115), e Berman (2006, cap. 7); para o segundo New Deal, ver Watkins (1993, caps. 8-9), e Rauchway (2008, cap. 6); para o Japão, Koike (1987, p. 292-293); para o manuscrito de Caio Prado Jr., ver Secco (2008, p. 80).

${ }^{46}$ O sociólogo Boaventura da Souza Santos captou a diferença perfeitamente: "Devemos notar que a lógica da austeridade já se tinha instalado no segundo mandato de Dilma. Mas há uma diferença qualitativa. Com o governo do PT essa lógica traduzia-se em algumas medidas de emergência e com a crença equivocada de permitirem a curto prazo o regresso à normalidade de uma governação minimamente inclusiva no plano social. Com o governo Temer, tais medidas, um menu imenso, são a nova normalidade" (MARTINS, 2016). Em discurso no Conselho das Américas em Washington em 21/09/2016, buscando atrair investidores para o Brasil, Temer admitiu o papel do programa da Ponte para o Futuro no golpe: "E há muitíssimos meses atrás, eu ainda vice-presidente, lançamos um documento chamado 'Uma Ponte Para o Futuro, porque nós verificávamos que seria impossível o governo continuar naquele rumo. E até sugerimos ao governo que adotasse as teses que nós apontávamos naquele documento chamado 'Ponte para o futuro'. E, como isso não deu certo, não houve adoção, instaurou-se um processo que culminou agora com a minha efetivação como Presidência da República" (VIEIRA, 2016). Para uma interpretação dos objetivos do golpe de 2016 que enfatiza o programa Ponte para o Futuro, ver Bastos (2016b, 2016c, 2016d). 
As lições a serem retiradas da história são políticas, não morais, e a busca necessária de responsabilidades não pode nos prender a uma luta sobre o passado. Embora o dano político e econômico do "austericídio" fosse previsível, não era previsível que chegássemos a tamanho recuo. Ademais, o jogo da culpa pela derrota não pode nos absorver muito tempo, pois não temos tal tempo. $O$ futuro será muito duro, e a tarefa principal das esquerdas na conjuntura é unir forças, com a máxima solidariedade possível, para barrar a nova normalidade e, em contra-ataque, acumular forças para, de volta, revisar e reforçar a Constituição Federal do Brasil. Nada menos, daí para mais.

\section{REFERÊNCIAS}

AGUIAR, G. Janot adverte políticos contra manobra para barrar a Lava Jato. O Estado de São Paulo, 27/06/2016. Disponível em: <http://politica.estadao.com.br/noticias/geral,janot-adverte-politicos-contra-manobra-para-barrar-a-lava-jato,10000059593>. Acesso em: 31 jan. 2017.

ALMEIDA, R. À Sombra do Poder. Os bastidores da crise que derrubou Dilma Rousseff. São Paulo: LeYa, 2016.

ALVES et al. "Talvez devêssemos ter usado uma mão mais leve em 2011", avalia Mantega. $O$ Globo, 14/09/2013.

ANDERSON, P. Crisis in Brazil. London Review of Books, v. 38, n. 8 (21), p. 15-22, Apr. 2016.

AREND, M. "A industrialização do Brasil ante a nova divisão internacional do trabalho". In: BIANCARELLI, A. ; CALIXTRE, A.; CINTRA, M. (Orgs.). Presente e futuro do desenvolvimento brasileiro. Brasília: IPEA, 2015.

AVRITZER, L. Impasses da democracia no Brasil. Rio de Janeiro: Civilização Brasileira, 2016.

BALTAR, P.; KREIN, D. A retomada do desenvolvimento e a regulação do mercado do trabalho no Brasil. Caderno CRH, Salvador, v. 26, n. 68, p. 273-292, mai./ago. 2013.

BARBOSA, N. "Dez anos de política econômica”. In: SADER, E. (Org.) Dez anos de governos pós-neoliberais no Brasil: Lula e Dilma. São Paulo: Boitempo, 2013.

BARRETO, C. Dilma não está preocupada com popularidade, diz ministro. O Globo, 16/02/2016. Disponível em: <http://oglobo.globo.com/brasil/dilma-nao-esta-preocupada-com-popularidade-diz-ministro-18686039\#ixzz4T18qdzEJ>. Acesso em: 30 jan. 2017.

BARROCAL, A.; CARTA, M.; LIRIO, S. Entrevista de Dilma Rousseff: resistência até o fim. Carta Capital, n. 902, 22/05/2016.

BASTOS, P. P. Z. As aporias do liberalismo periférico: comentários à luz dos governos Dutra (1946-1950) e Cardoso (1994-2002). Economia e Sociedade, v. 12, p. 245-274, 2003.

BASTOS, P. P. Z. O presidente desiludido: a campanha liberal e o pêndulo de política econômica no governo Dutra (1942-1948). História Econômica e História de Empresas, v. 7, p. 99-136, 2004. 
BASTOS, P. P. Z. “A integração comercial da América do Sul no mundo pós-crise: desafios para o Brasil”. In: CARNEIRO, R.; MATIJASCIC, M. (Orgs.) Desafios do desenvolvimento brasileiro. Campinas: UNICAMP, 2010; Brasília: IPEA, 2011.

BASTOS, P. P. Z. Economia política da integração da América do Sul no mundo pós crise. Campinas: UNICAMP, Observatório da Economia Global, 2012a. Disponível em: <http://www. iececon.net/foco.htm>. Acesso em: 29 jan. 2017.

BASTOS, P. P. Z. A economia política do novo-desenvolvimentismo e do social desenvolvimentismo. Economia e Sociedade, v. 21, número especial, dez. 2012b.

BASTOS, P. P. Z. "Ascensão e crise do projeto nacional-desenvolvimentista de Getúlio Vargas". In: BASTOS. P.; FONSECA, P. (Orgs.) A Era Vargas: desenvolvimentismo, economia e sociedade. São Paulo: UNESP, 2012c.

BASTOS, P. P. Z. Economic slowdown, popular revolt, and government response in today's Brazil. Los Angeles, CA: UCLA, Center for Social Theory and Comparative History, February, 2014a.

BASTOS, P. P. Z. O terceiro turno já começou. O austericídio também? Carta Maior, 22/10/2014, 2014b. Disponível em: <http://cartamaior.com.br/?/Editoria/Economia/O-terceiro-turnoja-comecou-O-austericidio-tambem-/7/32118>. Acesso em: 31 jan. 2017.

BASTOS, P. P. Z. Razões econômicas, não economicistas, do golpe de 1964. Texto para Discussão, IE/UNICAMP, n. 229, mar. 2014c.

BASTOS, P. P. Z. A Carta ao povo brasileiro, de Dilma Rousseff. Revista Política Social e Desenvolvimento, n. 13, 2015a.

BASTOS, P. P. Z. O fracasso da austeridade e a urgência de uma alternativa à esquerda. Carta Maior, 2015b. Disponível em: <http://cartamaior.com.br/?/Editoria/Economia/O-fracasso-da-austeridade-e-a-urgencia-de-uma-alternativa-a-esquerda/7/33047>. Acesso em: 28 jan. 2017.

BASTOS, P. P. Z. O impeachment de Dilma Rousseff e o programa do novo PMDB. Carta Maior, 09/12/2015, 2015c. Disponível em: <http://www.cartamaior.com.br/?/Editoria/ Economia/O-impeachment-de-Dilma-Rousseff-e-o-programa-do-novo-PMDB/7/35142>. Acesso em: 27 jan. 2017.

BASTOS, P. P. Z. "Austeridade permanente? A crise global do capitalismo neoliberal e as alternativas no Brasil”. In: BELLUZZO, L. G.; BASTOS, P. P. Z. (Orgs.) Austeridade para quem? Balanço e Perspectivas do governo Dilma Rousseff. São Paulo: Carta Maior e Friedrich Ebert Stiftung, 2015.

BASTOS, P. P. Z. Crescimento da dívida pública e política monetária no Brasil (1991-2014). Texto para Discussão, IE-UNICAMP, n. 273, $2016 \mathrm{a}$.

BASTOS, P. P. Z. Por que o impeachment é um golpe? Carta Maior, 15/04/2016, 2016b. Disponível em: <http://cartamaior.com.br/?/Editoria/Politica/Por-que-o-impeachment-e-umgolpe-/4/35965>. Acesso em: 31 jan. 2017.

BASTOS, P. P. Z. Quais os objetivos políticos do golpe? Carta Maior, 15/04/2016, 2016c. Disponível em: <http://cartamaior.com.br/?/Editoria/Politica/Quais-os-objetivos-politicos-dogolpe-/4/35966>. Acesso em: 31 jan. 2017. 
BASTOS,P.P.Z.Quaisosobjetivoseconômicosdogolpe?CartaMaior, 15/04/2016,2016d.Disponível em: <http://cartamaior.com.br/?/Editoria/Politica/Quais-os-objetivos-economicos-do-golpe-/4/35967>. Acesso em: 31 jan. 2017.

BASTOS et al. Manifesto dos economistas pelo desenvolvimento e pela inclusão social. Carta Maior, Economia, 06/11/2014, 2014a. Disponível em: <http://www.cartamaior.com.br/?/ Editoria/Economia/Manifesto-dos-economistas-pelo-desenvolvimento-e-pela-inclusaosocial/7/32180>. Acesso em: 31 jan. 2017.

BASTOS et al. Em defesa do programa vitorioso nas urnas. Carta Maior, 24/11/2014, 2014b. Disponível em: <http://www.cartamaior.com.br/?/Editoria/Politica/Em-defesa-do-programa-vitorioso-nas-urnas/4/32296>. Acesso em: 31 jan. 2017.

BASTOS, P. P. Z. Macroeconomia e mercado de trabalho: as principais teorias e o Brasil contemporâneo. Revista Ciências do Trabalho, n. 7, abr. 2017.

BASTOS, P. P. Z.; BELLUZZO, L. G. Uma crítica aos pressupostos do ajuste econômico. Folha de São Paulo, Ilustríssima, 09/10/2016. Disponível em: <http://www1.folha.uol.com.br/ ilustrissima/2016/10/1820798-uma-critica-aos-pressupostos-do-ajuste-economico.shtml >. Acesso em: 31 jan. 2017.

BASTOS, P. P. Z.; ROSSI, P. Combater a inflação com recessão é estratégia ultrapassada. Jornal do Brasil, 16/04/2017.

BASTOS, P. P. Z.; HIRATUKA, C. “A política econômica externa do governo Dilma Rousseff: comércio, cooperação e dependência. Texto para Discussão, IE-UNICAMP, n. 306, 2017.

BAUMOL, W. Macroeconomics of unbalanced growth: the anatomy of urban crisis. The American Economic Review, v. 57, n. 3, p. 415-426, jun. 1967.

BCB - BANCO CENTRAL DO BRASIL. Relatório de Economia Bancária e Crédito. Brasília, DF: BCB, 2014.

BELLUZZO, L. G.; BASTOS, P. P. Z. (Orgs.) Austeridade para quem? Balanço e Perspectivas do governo Dilma Rousseff. São Paulo: Carta Maior e Friedrich Ebert Stiftung, 2015.

BENSON, G. Political corruption in America. Lexington: Lexington Books, 1978.

BERINGER, T. A Fiesp e a política externa de José Serra. Carta Capital, 2016. Disponível em: $<$ https://www.cartacapital.com.br/blogs/blog-do-grri/a-fiesp-e-a-politica-externa-de-joseserra >. Acesso em: 29 jan. 2017

BERMAN, S. The primacy of politics: social democracy and the making of Europe's Twentieth Century. Cambridge: Cambridge University Press, 2006.

BLYTH, M. Great transformations: economic ideas and institutional change in the Twentieth Century. Cambridge: Cambridge University Press, 2002.

BOITO, A. O Golpe de 1954: a burguesia contra o populismo. São Paulo: Brasiliense, 1982.

BOITO, A. “Classe média e sindicalismo”. In: BOITO, A. (Org.) Estado, política e classes sociais: ensaios teóricos e históricos. São Paulo: Ed. UNESP, 2007.

BOITO, A. As bases políticas do neodesenvolvimentismo. In: FÓRUM DE ECONOMIA DA FUNDAÇÃO GETULIO VARGAS, 9, FGV, 2012a. Disponível em: <http://bibliotecadigital. fgv.br/dspace/handle/10438/16866>. Acesso em: 11 jan. 2017. 
BOITO, A. “Governo Lula: a nova burguesia nacional no poder”. In: BOITO JR, A.; GALVÃO, A. (Orgs.). Política e classes sociais no Brasil dos anos 2000. São Paulo: Alameda, 2012b.

BOITO, A. Lava Jato, classe média e burocracia de Estado. Revista Princípios, n. 142, mai./jul. 2016a.

BOITO, A. O conflito de classe por trás da crise institucional. Brasil de Fato, 07/12/2016, 2016b. Disponível em: <https:/www.brasildefato.com.br/2016/12/07/o-conflito-de-classe-portras-da-crise-institucional/>. Acesso em: 21/01/2017.

BOITO, A.; GALVÃO, A.; MARCELINO, A.. La nouvelle phase du syndicalisme brésilien (20032013). Cahiers des Amériques Latines, v. 80, n. 3, p. 147-167, 2015.

BRAGA, R. “Terra em transe: o fim do lulismo e o retorno da luta de classes". In: SINGER, A.; LOUREIRO, A. (Orgs.). As contradições do lulismo: a que ponto chegamos? São Paulo: Boitempo, 2016.

BRANDI, P. Vargas. Da vida para a História. Rio de Janeiro: Zahar, 1983.

CARDOSO DE MELLO, J. M.; NOVAIS, F. “Capitalismo tardio e sociabilidade moderna”. In: SCHWARTZ, L. História da vida privada no Brasil. São Paulo: Cia. das Letras, 1998.

CARDOSO, A. A construção da sociedade do trabalho no Brasil: uma investigação sobre a persistência secular das desigualdades. Rio de Janeiro: Ed. FGV/FAPERJ, 2010.

CARDOSO, J. C. Estrutura setorial-ocupacional do emprego no Brasil e evolução do perfil distributivo nos anos 90. Texto para Discussão, IE-UNICAMP, n. 85, 1999.

CARTA, M. A origem do complô. Carta Capital, n. 892, 14/03/2016. Disponível em: <http:// www.cartacapital.com.br/revista/892/a-origem-do-complo>. Acesso em: 12 jan. 2017.

CASTRO, J. A. Política social e desenvolvimento no Brasil. Economia e Sociedade, Campinas, v. 21, Número Especial, dez. 2012.

CAVALCANTE, S. Classe média e modo de produção capitalista: um estudo a partir do debate marxista. Tese (Doutorado em Sociologia) - Instituto de Filosofia e Ciências Humanas, Universidade Estadual de Campinas, Campinas, 2012.

CAVALCANTE, S. Reprodução social e revolta política da classe média no Brasil recente. In: ENCONTRO ANUAL DA ANPOCS, 39, Caxambu, MG, 2015.

CHAUI, M. As manifestações de junho de 2013 na cidade de São Paulo. Teoria e Debate, Ed.113, 27/06/2013. Disponível em: <http://www.teoriaedebate.org.br/materias/nacional/manifestacoes-de-junho-de-2013-na-cidade-de-sao-paulo?page $=$ full $>$.

CONTI, B.; PRATES, D. The International Monetary System hierarchy: current configuration and determinants. In: ANNUAL EAEPE CONFERENCE, 28, Manchester, UK, 03-05 Nov. 2016.

CORTÊS, M.; TRÓPIA, P. Pesquisa “Manifestando na Paulista”. INCIS/UFU, 2015. Disponível em: <https://www.facebook.com/permalink.php?story_fbid $=446731762172280$ \&id=426666257512164>. Acesso em: 27 jun. 2015.

DIEGUES, A. C. "As transformações no padrão de organização e acumulação da indústria: da desindustrialização à 'Doença Brasileira”'. In: BELLUZZO, L. G.; BASTOS, P. P. Z. (Orgs.) Austeridade para quem? Balanço e Perspectivas do governo Dilma Rousseff. São Paulo: Carta Maior e Friedrich Ebert Stiftung, 2015. 
DUAILIBI, J. Delegados da Lava Jato exaltam Aécio e atacam PT na rede. O Estado de S. Paulo, 13/11/2014. Disponível em: <http://politica.estadao.com.br/noticias/geral,delegados-da -lava-jato-exaltam-aecio-e-atacam-pt-na-rede,1591953>. Acesso em: 21 jan. 2017.

FAERMANN, P. Exclusiva: Dilma faz o diagnóstico invisível da sua gestão econômica. Jornal GGN, Política, 10/06/2016. Disponível em: <http://jornalggn.com.br/noticia/exclusivadilma-faz-o-diagnostico-invisivel-da-sua-gestao-economica>. Acesso em: 22 jan. 2017.

FABRINI, F. TCU proíbe Petrobras de vender ativos por irregularidades nos processos. O Estado de São Paulo, 07/12/2016. Disponível em: <http://economia.estadao.com.br/noticias/ geral,tcu-proibe-petrobras-de-vender-ativos-e-compromete-plano-de-desinvestimento-da -estatal,10000093201>. Acesso em: 11 jan. 2017.

FERNANDES, F. A integração do negro na sociedade de classes. Vol. 2 (No limiar de uma nova era). São Paulo: Ed. Globo, 2008.

FERNANDES, M. C. O maluco solitário e o Ministério Público. Valor Econômico, Cultura, 23/09/2016. Disponível em: <http://www.valor.com.br/cultura/4719497/o-maluco-solitario-e-o-ministerio-publico>. Acesso em: 17 jan. 2017.

FIESP - FEDERAÇÃO DAS INDÚSTRIAS DO ESTADO DE SÃO PAULO. Brasil com Juros Baixos, 2011. Disponível em: <www.fiesp.com.br/por_um_brasil_com_juros_baixos/>. Acesso em: 21 jan. 2017.

FÓRUM. Delegado da PF que indiciou Lula era cabo eleitoral de Aécio Neves. Revista Fórum, 26/08/2016, 2016a. Disponível em: <http://www.revistaforum.com.br/2016/08/26/delegado-da-pf-que-indiciou-lula-era-cabo-eleitoral-de-aecio-neves/>. Acesso em: 22 jan. 2017.

FÓRUM. Delegado que indiciou Lula o chamou de anta e postou foto com logo da Globo no Facebook. Revista Fórum, 12/12/2016, 2016b. Disponível em: <http://www.revistaforum. com.br/blogdorovai/2016/12/12/delegado-que-indiciou-lula-o-chamou-de-anta-e-postoufoto-com-logo-da-globo-no-facebook/>. Acesso em: 23 jan. 2017.

FPA - FUNDAÇÃO PERSEU ABRAMO. Pesquisa Manifestações de Março/2015. São Paulo: Fundação Perseu Abramo, 2015.

FURNO, J. A longa abolição no Brasil: transformações recentes no trabalho doméstico. Dissertação (Mestrado em Desenvolvimento Econômico) - Instituto de Economia, Universidade Estadual de Campinas, Campinas, 2016.

GALVÃO, A. Political action of the Brazilian labour movement: issues and contradictions facing PT governments. Studies in Political Economy, v. 97, n. 3, 2016 a.

GALVÃO, A. As classes médias na crise política brasileira. Blog, 27/06/2016, 2016b. Disponível em: <http://blogjunho.com.br/as-classes-medias-na-crise-politica-brasileira/>. Acesso em: 17 jan. 2017.

GOBETTI, S.; ORAIR, R. Distribuição e tributação de renda no Brasil: novas evidências a partir das declarações fiscais das pessoas físicas. In: ENCONTRO NACIONAL DE ECONOMIA DA ANPEC, 43, Florianópolis, 8-11, dez. 2015. Disponível em: <http://www.anpec.org.br/ novosite/br/encontro-2015>. Acesso em: 12 jan. 2017.

GORENDER, J. Marxismo sem utopia. São Paulo: Ática, 1999.

GROSSMAN, M. Political corruption in America: an encyclopedia of scandals, power, and greed. 2. ed. Millerton: Grey House Publishing, Inc., 2008. 
HIRATUKA, C. "Padrões de integração comercial das filiais de empresas transnacionais". In: LAPLANE, M.; COUTINHO, L.; HIRATUKA, C. Internacionalização e desenvolvimento da indústria no Brasil. São Paulo: UNESP; Campinas: IE-UNICAMP, 2003.

HIRATUKA, C.; DE NEGRI, F. Notas sobre a influência da origem do capital sobre os padrões regionais de comércio exterior brasileiro. Revista Economia, Curitiba, v. 28, p. 333-360, $2002 / 2003$.

HIRATUKA, C. “Mudanças na estrutura produtiva global e a inserção brasileira: desafios no cenário pós-crise". In: CGEE. Transformações produtivas e patrimoniais na economia mundial e impactos sobre a economia brasileira. Brasília: CGEE, 2017 (No prelo).

HORIE, L. M. Política econômica, dinâmica setorial e a questão ocupacional no Brasil. Tese (Doutorado em Desenvolvimento Econômico) - Instituto de Economia, Universidade Estadual de Campinas, Campinas, 2012.

INEP - INSTITUTO NACIONAL DE ESTUDOS E PESQUISAS EDUCACIONAIS ANÍSIO TEIXEIRA. Censo da educação superior 2009: resumo técnico. Brasília: INEP, 2010.

INEP - INSTITUTO NACIONAL DE ESTUDOS E PESQUISAS EDUCACIONAIS ANÍSIO TEIXEIRA. Censo da educação superior 2013: resumo técnico. Brasília: INEP, 2015.

JUDIS, J. The populist explosion: how the great recession transformed American and European politics. Columbia Global Reports, 2016.

KALECKI, M. Political aspects of full employment. Political Quarterly, v.14, n. 4, p. 322-331, 1943.

KLEIN, C. O “Trump brasileiro" que vê índios como entrave à economia. Valor Econômico, Política, 29/02/2016. Disponível em: <http://www.valor.com.br/politica/4458092/o-trump -brasileiro-que-ve-indios-como-entrave-economia>. Acesso em: 19 jan. 2017.

KOFES, S. Mulheres, mulheres: identidade, diferença e desigualdade na relação entre patroas e empregadas. Campinas: Editora da UNICAMP, 2001.

KOIKE, K. "Human resource development and labor-management relations". In: YAMAMURA, K.; YASUBA, Y. The Political Economy of Japan: The Domestic Transformation. Palo Alto: Stanford Univ. Press, 1987.

KREIN, J.; BIAVASCHI, M. Brasil: os movimentos contraditórios da regulação do trabalho dos anos 2000. Cuadernos del CENDES, v. 32, n. 89, p. 47-82, mai./ago. 2015.

LIMA, M. FH diz que Dilma deve "abrir os olhos" sobre manifestações e cuidar da inflação. O Globo, Brasil, 18/06/2013. Disponível em: <http://oglobo.globo.com/brasil/fh-diz-quedilma-deve-abrir-os-olhos-sobre-manifestacoes-cuidar-da-inflacao-8731518\#ixzz3eXlzKObA)>. Acesso em: 03 mar. 2015.

MAIA, A. G. Espacialização de classes sociais no Brasil. Tese (Doutorado em Desenvolvimento Econômico) - Instituto de Economia, Universidade Estadual de Campinas, Campinas, 2006.

MANTEGA, G. O primeiro ano da nova matriz. Valor Econômico, 19/12/2012.

MARCOLINO, L. C.; CARNEIRO, R. (Orgs.) Sistema financeiro e desenvolvimento no Brasil: do Plano Real à crise financeira. São Paulo: Publisher Brasil e Editora Gráfica Atitude, 2010.

MARICATO, E. Cidades no Brasil: neodesenvolvimentismo ou crescimento periférico predatório? Revista Política Social e Desenvolvimento, n. 1, 2013. 
MARTINS, M. Entrevista com Boaventura Santos. "O que mais custa aceitar é a participação do Judiciário no golpe”. Carta Capital, Política, 02/11/2016. Disponível em: <http://www. cartacapital.com.br/politica/o-que-mais-custa-aceitar-e-a-participacao-do-judiciario-nogolpe >. Acesso em: 31 jan. 2017.

MARTUSCELLI, D. A ideologia do “presidencialismo de coalizão”. In: SIMPÓSIO LUTAS SOCIAIS NA AMÉRICA LATINA, 4, Londrina, UEL, 14-17 set. 2010.

MATTOS, F.; LIMA, S. Apontamentos para o debate sobre o pleno emprego no Brasil. Economia e Sociedade, Campinas, v. 24, n. 2 (54), p. 293-328, ago. 2015.

MEDEIROS, M.; SOUZA, P.; CASTRO, F. O topo da distribuição de renda no Brasil: Primeiras estimativas com dados tributários e comparação com pesquisas domiciliares (2006-2012). Revista de Ciências Sociais, v. 58, n. 1, 2015.

MELO, H. P. de. O Serviço doméstico remunerado no Brasil: de criadas a trabalhadoras. Texto para Discussão, IPEA, Rio de Janeiro, n. 565, p. 1-29, 1998.

MITERHOF, M. O problema é o crescimento. Folha de São Paulo, 18/07/2013.

MORAIS, F. Chatô: o rei do Brasil. São Paulo: Companhia das Letras, 1994.

MORCEIRO, P. Vazamento de demanda setorial e competitividade da indústria de transformação brasileira. Working Paper Series, FEA-USP, n. 2016-12.

MORO, S. Considerações sobre a Operação ManiPulite. Brasília: Conselho da Justiça Federal, Centro de Estudos Judiciários, n. 26, p. 56-62, jul./set. 2004.

MPF - MINISTÉRIO PÚBLICO FEDERAL. Anexo Pessoal: Delação de Cláudio Melo Filho, da Odebrecht. Disponível em: <http://politica.estadao.com.br/blogs/fausto-macedo/wp-content/uploads/sites/41/2016/12/Claudio-Melo-Filho-_sem-marca-de-revisa\%CC\%83o_-1. pdf>. Acesso em: 02 jan. 2017.

NERY, N. Dilma afirma que errou na avaliação da situação econômica. Folha de São Paulo, Poder, 24/08/2015. Disponível em: <http://www1.folha.uol.com.br/poder/2015/08/1673024governo-demorou-para-perceber-gravidade-da-crise-economica-diz-dilma.shtml $>$. Acesso em: 18 jan. 2017.

NOBRE, M. 1988 + 30. Novos estudos CEBRAP, v. 35, n. 2, p. 135-149, jul. 2016.

O ESTADO DE SÃO PAULO. Em discurso, Janot fala em "gestão desastrosa" na Petrobras; veja a íntegra. O Estado de São Paulo, 09/12/2014. Disponível em: <http://politica.estadao.com. $\mathrm{br} /$ noticias/geral,em-discurso-janot-fala-em-gestao-desastrosa-na-petrobras-veja-a-integra,1604416>. Acesso em: 31 jan. 2017.

ORTEllADO, P.; SOLANO, E. Pesquisa manifestação política 12 de abril de 2015. Disponível em: https://gpopai.usp.br/pesquisa/120415/. Acesso em: 12 de ago. 2015.

ORTELLADO, P.; SOLANO, E.; NADER, L. Pesquisa manifestação política 16 de agosto de 2015. Disponível em: <https:/gpopai.usp.br/pesquisa/160815//>. Acesso em: 31 jan. 2017.

PINOTTI, A. C.; PASTORE, M. C. Desafio do ajuste cambial. Folha de São Paulo, 14 dez. 2014.

POCHMANN, M. "Políticas públicas e situação social na primeira década do século XXI”. In: SADER, E. (Org.) Dez anos de governos pós-neoliberais no Brasil: Lula e Dilma. São Paulo: Boitempo, 2013. 
POCHMANN, M. O mito da grande classe média: capitalismo e estrutura social. São Paulo: Boitempo, 2014.

POCHMANN, M. “Impasse entre mobilidade e polarização recentes no capitalismo brasileiro”. In: BELLUZZO, L. G.; BASTOS, P. P. Z. (Orgs.) Austeridade para quem? Balanço e Perspectivas do governo Dilma Rousseff. São Paulo: Carta Maior e Friedrich Ebert Stiftung, 2015.

PRATES, D. O regime de câmbio flutuante no Brasil (1999-2012): especificidades e dilemas. Brasília: IPEA, 2015.

QUADROS, W. O milagre brasileiro e a expansão da nova classe média. Tese (Doutorado em Desenvolvimento Econômico) - Instituto de Economia, Universidade Estadual de Campinas, Campinas, 1991.

QUADROS, W. A evolução recente das classes sociais no Brasil. Campinas: Unicamp, 2002.

QUADROS, W. Melhorias sociais no período 2004 a 2008. Texto para Discussão, IE-UNICAMP, n. 176, 2010.

QUADROS, W. 2009 a 2012: heterodoxia impulsiona melhorias sociais. Texto para Discussão, IE-UNICAMP, n. 230, 2014.

QUADROS, W. Paralisia econômica, retrocesso social e eleições. Texto para Discussão, IE-UNICAMP, n. 249, 2015.

QUADROS; W.; MAIA, A. G. Estrutura sócio-ocupacional no Brasil. Revista de Economia contemporânea, v. 14, n. 3, p. 443-468, set./dez. 2010.

QUIGGIN, J. Zombieeconomics. 2.ed. Princeton: Princeton University Press, 2012.

RAUCHWAY, E. The Great Depression and the New Deal. Oxford: Oxford University Press, 2008.

REGO, W. L.; PINZANI, A. Vozes do Bolsa Família: autonomia, dinheiro e cidadania. São Paulo: Editora da Unesp, 2013.

REMY, M. A. Mobilidade brasileira a partir de estratos de renda: 1981 a 2004. Tese (Doutorado em Desenvolvimento Econômico) - Instituto de Economia, Universidade Estadual de Campinas, Campinas, 2008.

ROSSI, P. Taxa de câmbio e política cambial no Brasil: teoria, institucionalidade, papel da arbitragem e da especulação. São Paulo: FGV Editora, 2016.

ROUSSEFF, D. Discurso na sessão final do processo de impeachment. Senado Federal, 28/08/2016. Disponível em: < http://www.ebc.com.br/noticias/politica/2016/08/confira-integra-do-discurso-de-dilma-rousseff-no-senado>. Acesso em: 02 jan. 2017.

RUGITSKY, F. “Do ensaio desenvolvimentista à austeridade: uma leitura Kaleckiana”. In BELLUZZO, L. G.; BASTOS, P. P. Z. (Orgs.) Austeridade para quem? Balanço e Perspectivas do governo Dilma Rousseff. São Paulo: Carta Maior e Friedrich Ebert Stiftung, 2015.

SAES, D. Classe média e política na Primeira República brasileira (1989-1930). Petrópolis: Vozes, 1975.

SAES, D. Classe média e políticas de classe (uma nota teórica). Contraponto, n. 2, 1977.

SAES, D. “Classe média e política no Brasil (1930-1964)”. In: FAUSTO, B. (Org.). O Brasil Republicano. Vol. III. São Paulo: Difel, 1981.

SAES, D. Classe média e sistema político no Brasil. São Paulo: T. A. Queiroz, 1985a. 
SAES, D. A formação do Estado burguês no Brasil (1888-1891). Rio de Janeiro: Paz e Terra, 1985b.

SAES, D. A contestação à ordem monárquica no Brasil. Primeira Versão, UNICAMP, n. 49, 1992.

SAES, D. Classe média e escola capitalista. Crítica Marxista, n. 21, 2005.

SALINGER, L. Encyclopedia of white-collar and corporate crime. 2. ed. Thousand Oaks: SAGE Publications, Inc., 2013.

SANTOS, W. G. “A práxis liberal no Brasil”. In: SANTOS, W. G. Décadas de espanto e uma apologia democrática. São Paulo: Rocco, 1998.

SARAMAGO, H. Trajetória da parcela dos salários na renda no Brasil: análise de decomposição a partir do salário real e da produtividade (1990-2013). Dissertação (Mestrado em Economia) - Instituto de Economia, Universidade Federal do Rio de Janeiro, Rio de Janeiro, 2016.

SCHERER, C. Payroll tax reduction in Brazil: effects on employment and wages. ISS Working Paper Series/General Series, n. 602, p. 1-64, 2015.

SCHUI, F. Austerity: The Great Failure. New Haven: Yale University Press, 2014.

SECCO, L. Caio Prado Júnior: o sentido da revolução. São Paulo: Boitempo, 2008.

SENADO. Levy apoia emenda que limita dívida da União. Jornal do Senado, ano XXI, n. 4.419, 19 de nov. de 2015. Disponível em: <https:/www12.senado.leg.br/jornal/edicoes/2015/11/19/ jornal.pdf\#page=1>. Acesso em: 02 jan. 2017.

SICSÚ, J. Dez anos que abalaram o Brasil. E o futuro? São Paulo: Geração Editorial, 2014.

SINGER, A. Cutucando onças com varas curtas: o ensaio desenvolvimentista no primeiro mandato de Dilma Rousseff (2011-2014). Novos Estudos Cebrap, n. 102, jul. 2015.

SINGER, A. Jogo viciado. Folha de São Paulo, 19/03/2016, 2016a. Disponível em: <http://www1. folha.uol.com.br/colunas/andresinger/2016/03/1751793-jogo-viciado.shtml>. Acesso em: 22 jan. 2017.

SINGER, A. Roteiro de um golpe? Folha de São Paulo, 26/03/2016, 2016b. Disponível em: $<$ http://www1.folha.uol.com.br/colunas/andresinger/2016/03/1754234-roteiro-de-umgolpe.shtml>. Acesso em: 22 jan. 2017.

SINGER, A. É hora de barrar o arbítrio. Folha de S. Paulo, 24 set. 2016c. Disponível em: <http:// wwwl.folha.uol.com.br/colunas/andresinger/2016/09/1816410-e-hora-de-barrar-o-arbitrio.shtml>. Acesso em: 22 jan. 2017.

SOUZA, J. (Org.) Ralé brasileira: quem é e como vive. Belo Horizonte: Editora UFMG, 2009.

SOUZA, J. A tolice da inteligência brasileira: ou como o país se deixa manipular pela elite. São Paulo: LeYa, 2015.

SOUZA, J. A Radiografia do Golpe: entenda como e por que você foi enganado. São Paulo: LeYa, 2016.

STREECK, W. The crises of democratic capitalism. New Left Review, n. 71, p. 5-29, 2011.

STREECK, W. Buying time: the delayed crisis of democratic capitalism. London: Verso, 2014.

TEACHOUT, Z. Corruption in America: from Benjamin Franklin's snuff box to Citizens United. Cambridge: Harvard University Press, 2014. 
TOLEDO, C. N. O governo Goulart e o golpe de 64. São Paulo: Brasiliense, 1984.

TRÓPIA, P. A inserção de classe dos assalariados não-manuais: um debate com a bibliografia marxista. Cadernos CEMARX, Campinas, n. 1, 2004.

VALENTE, R. Em diálogos gravados, Jucá fala em pacto para deter avanço da Lava Jato. Folha de S. Paulo, 23/05/2016.

VIEIRA, I. Michel Temer diz que impeachment aconteceu porque Dilma rejeitou "Ponte para o Futuro". The Intercept, 22/092016. Disponível em: <https://theintercept.com/2016/09/22/ michel-temer-diz-que-impeachment-aconteceu-porque-dilma-rejeitou-ponte-para-o-futuro/>. Acesso em: 31 jan. 2017.

VOLPON, T. A globalização e a política: de FHC a Lula. Rio de Janeiro: Revan, 2003.

VOLPON, T. Brazil: Dilma 2.0. Nomura Economic Insights: Emerging Markets. Global Markets Research, 22/09/2014.

Watkins, T. H. (1993) The Great Depression: America in the 1930s. Boston: Little, Brown and Company, 2009.

ZUCMAN, G. The Hidden wealth of nations: the scourge of tax havens. Chicago: Chicago University of Chicago Press, 2015. 